\title{
Article
}

\section{Mn-bearing purplish-red tourmaline from the Anjanabonoina pegmatite, Madagascar}

\author{
Ferdinando Bosi ${ }^{1 \star}$ (D), Beatrice Celata ${ }^{1}$, Henrik Skogby², Ulf Hålenius², Gioacchino Tempesta ${ }^{3}$, Marco E. Ciriotti ${ }^{4,5}$, \\ Erica Bittarello ${ }^{5,6}$ and Alessandra Marengo 5,6 \\ ${ }^{1}$ Department of Earth Sciences, Sapienza University of Rome, Piazzale Aldo Moro 5, I-00185 Rome, Italy; ${ }^{2}$ Department of Geosciences, Swedish Museum of Natural \\ History, SE-10405 Stockholm, Sweden; ${ }^{3}$ Department of Earth and Geoenvironmental Sciences, University of Bari "Aldo Moro", via Orabona 4, I-70125 Bari, Italy; \\ ${ }^{4}$ Associazione Micromineralogica Italiana, via San Pietro 55, I-10073 Devesi-Cirié, Italy; ${ }^{5}$ Department of Earth Sciences, University of Turin, via Tommaso Valperga \\ Caluso 35, I-10125 Torino, Italy; and ${ }^{6}$ SpectraLab s.r.l. Academic spin-off of the University of Turin, via Tommaso Valperga Caluso 35 , I-10125 Torino, Italy
}

\begin{abstract}
A gem-quality purplish-red tourmaline sample of alleged liddicoatitic composition from the Anjanabonoina pegmatite, Madagascar, has been fully characterised using a multi-analytical approach to define its crystal-chemical identity. Single-crystal X-ray diffraction, chemical and spectroscopic analysis resulted in the formula: ${ }^{\mathrm{X}}\left(\mathrm{Na}_{0.41} \square_{0.35} \mathrm{Ca}_{0.24}\right)_{\Sigma 1.00}{ }^{\mathrm{Y}}\left(\mathrm{Al}_{1.81} \mathrm{Li}_{1.00} \mathrm{Fe}_{0.04}^{3+} \mathrm{Mn}_{0.02}^{3+} \mathrm{Mn}_{0.12}^{2+} \mathrm{Ti}_{0.004}\right)_{\Sigma 3.00}{ }^{\mathrm{Z}} \mathrm{Al}_{6}$ $\left[{ }^{\mathrm{T}}\left(\mathrm{Si}_{5.60} \mathrm{~B}_{0.40}\right)_{\Sigma 6.00} \mathrm{O}_{18}\right]\left(\mathrm{BO}_{3}\right)_{3}(\mathrm{OH})_{3}{ }^{\mathrm{W}}\left[(\mathrm{OH})_{0.50} \mathrm{~F}_{0.13} \mathrm{O}_{0.37}\right]_{\Sigma 1.00}$ which corresponds to the tourmaline species elbaite having the typical space group $R 3 m$ and relatively small unit-cell dimensions, $a=15.7935(4) \AA, c=7.0860(2) \AA$ and $V=7.0860(2) \AA^{3}$.

Optical absorption spectroscopy showed that the purplish-red colour is caused by minor amounts of $\mathrm{Mn}^{3+}\left(\mathrm{Mn}_{2} \mathrm{O}_{3}=0.20\right.$ wt.\%). Thermal treatment in air up to $750^{\circ} \mathrm{C}$ strongly intensified the colour of the sample due to the oxidation of all $\mathrm{Mn}^{2+}$ to $\mathrm{Mn}^{3+}$ $\left(\mathrm{Mn}_{2} \mathrm{O}_{3}\right.$ up to $1.21 \mathrm{wt}$ \%). Based on infrared and Raman data, a crystal-chemical model regarding the electrostatic interaction between the $\mathrm{X}$ cation and $\mathrm{W}$ anion, and involving the $\mathrm{Y}$ cations as well, is proposed to explain the absence or rarity of the mineral species 'liddicoatite'.
\end{abstract}

Keywords: purplish-red tourmaline, crystal-structure refinement, electron microprobe, laser induced breakdown spectroscopy, Raman spectroscopy, infrared spectroscopy, optical absorption spectroscopy

(Received 16 December 2020; accepted 24 February 2021; Accepted Manuscript published online: 1 March 2021; Associate Editor: Ian T. Graham)

\section{Introduction}

Tourmaline is the most common and the earliest-formed boron mineral on Earth and has recently received increasing interest from the geoscience community (Grew et al., 2016; Dutrow and Henry, 2018; Henry and Dutrow, 2018). Tourmaline minerals are complex borosilicates that have been studied extensively in terms of their crystal structure and crystal chemistry (e.g. Foit, 1989; Grice and Ercit, 1993; Ertl et al., 2002; Novák et al., 2004; Bosi and Lucchesi, 2007; Bosi 2013, 2018; Novák et al., 2011; Henry and Dutrow, 2011; Henry et al., 2011; Cempírek et al., 2013; Ertl et al., 2018; Andreozzi et al., 2020).

The general chemical formula of tourmaline can be written as: $\mathrm{XY}_{3} \mathrm{Z}_{6} \mathrm{~T}_{6} \mathrm{O}_{18}\left(\mathrm{BO}_{3}\right)_{3} \mathrm{~V}_{3} \mathrm{~W}$, where $\mathrm{X}=\mathrm{Na}, \mathrm{K}, \mathrm{Ca}$ and $\square$ (= vacancy); $\mathrm{Y}=\mathrm{Al}, \mathrm{Cr}, \mathrm{V}, \mathrm{Fe}, \mathrm{Mg}, \mathrm{Mn}, \mathrm{Zn}, \mathrm{Cu}, \mathrm{Li}$ and $\mathrm{Ti} ; \mathrm{Z}=\mathrm{Al}, \mathrm{Cr}, \mathrm{V}, \mathrm{Fe}$ and $\mathrm{Mg} ; \mathrm{T}=\mathrm{Si}, \mathrm{Al}$ and $\mathrm{B}^{3+} ; \mathrm{B}=\mathrm{B}^{3+} ; \mathrm{V}=(\mathrm{OH})$ and $\mathrm{O}$; and $\mathrm{W}=(\mathrm{OH})$, $\mathrm{F}$ and $\mathrm{O}$. Note that the non-italicised letters $\mathrm{X}, \mathrm{Y}, \mathrm{Z}$ and $\mathrm{B}$ represent groups of cations hosted at the ${ }^{[9]} X,{ }^{[6]} Y,{ }^{[6]} Z,{ }^{[4]} T$ and

\footnotetext{
*Author for correspondence: Ferdinando Bosi, Email: ferdinando.bosi@uniromal.it Cite this article: Bosi F., Celata B., Skogby H., Hålenius U., Tempesta G., Ciriotti M.E., Bittarello E. and Marengo A. (2021) Mn-bearing purplish-red tourmaline from the Anjanabonoina pegmatite, Madagascar. Mineralogical Magazine 85, 242-253. https:// doi.org/10.1180/mgm.2021.20
}

${ }^{[3]} B$ crystallographic sites (letters italicised). The letters $\mathrm{V}$ and $\mathrm{W}$ represent groups of anions accommodated at the ${ }^{[3]} \mathrm{O} 3$ and ${ }^{[3]} \mathrm{O} 1$ crystallographic sites, respectively. The $\mathrm{H}$ atoms occupy the $\mathrm{H} 3$ and $\mathrm{H} 1$ sites, which are related to $\mathrm{O} 3$ and $\mathrm{O} 1$, respectively. The dominance of specific ions at one or more sites of the structure gives rise to a range of distinct mineral species.

Tourmaline-supergroup minerals are currently classified into three groups, vacant, alkali and calcic, based on the $X$-site occupancy (Henry et al., 2011). The $X$-site occupancy is usually related to both paragenesis and crystallisation conditions of the host rock, and these relations may be used to reconstruct the host-rock thermal and chemical history (e.g. Henry and Dutrow, 1996; van Hinsberg et al., 2011a,b; Dutrow and Henry, 2018; Bosi et al., 2018, 2019c; Ahmadi et al., 2019). A further level of classification into subgroups is based on charge arrangements at the $Y$ and $Z$ sites. Tourmalines are also distinguished by the dominant anion at the $\mathrm{W}$ position of the general formula into hydroxy-, fluorand oxy-species.

Tourmaline is also one of the most important gem materials on the market today, particularly renowned for its spectrum of colours: from colourless, through red, pink, yellow, orange, green, blue and violet, to brown and black (Pezzotta and Laurs, 2011). The transition elements ( $\mathrm{Ti}, \mathrm{V}, \mathrm{Cr}, \mathrm{Fe}, \mathrm{Mn}$ and $\mathrm{Cu}$ ) are

(C) The Author(s), 2021. Published by Cambridge University Press on behalf of The Mineralogical Society of Great Britain and Ireland. This is an Open Access article, distributed under the terms of the Creative Commons Attribution licence (http://creativecommons.org/licenses/by/4.0/), which permits unrestricted re-use, distribution, and reproduction in any medium, provided the original work is properly cited. 
often invoked as colour-causing agents. Red tourmalines are commonly given the varietal name 'rubellite', which refers to tourmalines with colours ranging from rose, dark pink to purplish red, but do correspond to several regular mineral species: elbaite, fluor-elbaite, rossmanite, fluor-liddicoatite (Pezzotta and Laurs, 2011) and oxy-dravite (Bosi and Skogby, 2013).

Specifically, fluor-liddicoatite was redetermined and renamed in 2011 by the Subcommittee on Tourmaline Nomenclature of the International Mineralogical Association's Commission on New Minerals, Nomenclature and Classification (IMA-CNMNC) when the nomenclature of tourmaline-supergroup minerals was reconsidered (Henry et al., 2011) and the 'liddicoatite' from the Antandrokomby type locality (Dunn et al., 1977; Aurisicchio et al., 1999; Webber, 2002; Dirlam et al., 2002; Ertl et al., 2006; Lussier et al., 2011; Lussier and Hawthorne, 2011) regained proper attention. Note that with the renaming of the type material as fluorliddicoatite, the hydroxy species 'liddicoatite' is no longer properly defined as a species. A new type material definition is necessary to re-establish the name. Two gem-quality samples of purplish-red prismatic crystals of alleged 'liddicoatite' on quartz matrix from the collection of M.E. Ciriotti (MEC) were analysed with a Jeol JSM IT300LV scanning electron microscope (SEM) and energy dispersive X-ray spectroscopy (EDS) (University of Turin, Earth Sciences Department) to verify if they were F-dominant species. Although $\mathrm{B}$ and Li were not measured, both samples were determined to be F-dominant and were classified as fluor-liddicoatite. A small portion of a further alleged 'liddicoatite' sample (presented as 'probed' liddicoatite by its seller) in quartz-rhodizite matrix from Antandrokomby localities (the same type of purplish-red crystals are shown in the specimen in Fig. 1) was obtained by MEC, courtesy of the new owner. The sample was analysed through SEM-EDS and surprisingly showed no trace of $\mathrm{F}$; in addition, its composition did not fit 'liddicoatite' in terms of $\mathrm{Na}$ and $\mathrm{Ca}$.

In the present study, such a tourmaline sample from the Anjanabonoina pegmatite, central Madagascar, has been fully characterised by X-ray single-crystal diffraction, electron microprobe analysis, laser induced breakdown spectroscopy, micro-Raman, infrared and optical absorption spectroscopy, with the aim of defining its crystal-chemical identity and species.

\section{Occurrence}

The indexed stout prismatic purplish-red crystal was labelled (by the supplier) 'liddicoatite' from Anjanabonoina pegmatites, Ambohimanambola, Betafo, Vakinankaratra, Madagascar, $\sim 55 \mathrm{~km}$ west-southwest of the city of Antsirabe. In addition to Anjanabonoina, 'liddicoatite' has been identified from several localities in central and south-central Madagascar, including Antaboaka, Jochy, Lacamisinten, Malakialina, Maroandro and the Sahatany Valley, as well as Vohitrakanga (De Vito, 2002a,b; Dirlam et al., 2002), but the present labelled locality is correct (F. Pezzotta, personal communication).

The Anjanabonoina aplite-pegmatite field is situated in the Neoproterozoic Itrembo Group, which consists of a lower unit of gneisses and an upper unit of quartzites, schists and marbles (Pezzotta and Franchi, 1997; Fernandez et al., 2001). The pegmatites were emplaced in a complex geological environment, perhaps at the contact between the lower and upper unit. The gem-bearing pegmatites postdate the main tectonic phase and, therefore, are thought to have intruded during a late phase of the magmatic cycle about $490 \mathrm{Ma}$ (Paquette and Nédélec, 1998). The Li-Cs$\mathrm{Ta}$ (with minor $\mathrm{Nb}-\mathrm{Y}-\mathrm{F}$ ) aplite-pegmatite field extends for $\sim 2.5 \mathrm{~km}$. The veins are 2 to $12 \mathrm{~m}$ thick and large parts are kaolinised feldspars and/or deeply weathered (De Vito, 2002a,b).

More details about the history of the 1500s to 2000s explorations and mining of the Malagasy tourmaline gem deposits can be found in Strunz (1979), Pezzotta (1999) and Dirlam et al. (2002).

\section{Experimental methods and results}

\section{Thermal treatment}

In order to study potential dehydration and redox effects, two oriented and polished crystals were heat treated in air at $700^{\circ} \mathrm{C}$ $(20 \mathrm{~h})$ and $750^{\circ} \mathrm{C}(90 \mathrm{~h})$. These thermal conditions have previously been shown to be sufficient to impose changes in $\mathrm{Fe}$ redox states and intracrystalline cation distribution (e.g. Filip et al., 2012; Bosi et al., 2016a,b). The 55 and $309 \mu \mathrm{m}$ thick samples were placed in a gold container and inserted in a preheated

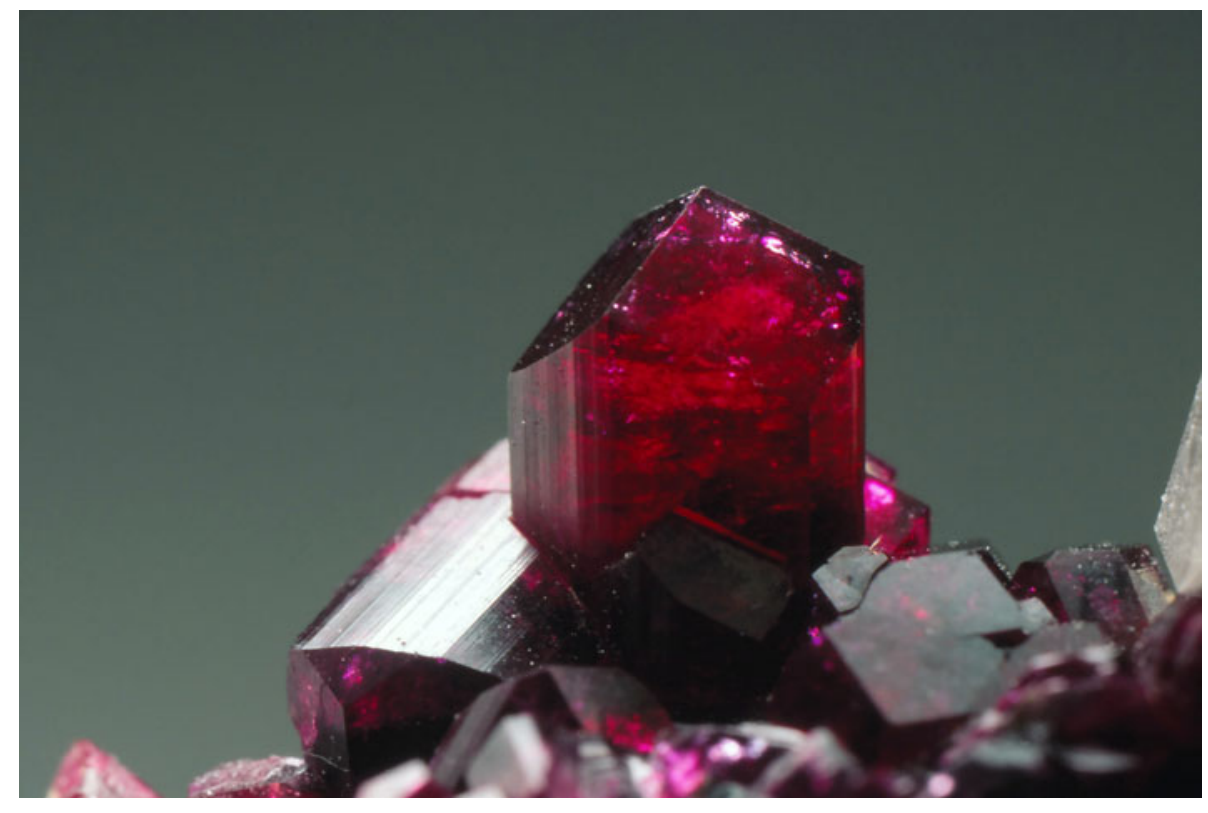

Fig. 1. Crystals of Mn-bearing purplish-red tourmaline from Madagascar, up to $1 \mathrm{~cm}$ in size (field of view ca. $5 \mathrm{~cm}$ ). Sample deposited in the collections of the Natural History Museum of Milano, Italy (photo by R. Appiani). 
Fig. 2. Microphoto of Mn-bearing tourmaline from Madagascar before (on the left) and after (on the right) heat treatment at $750^{\circ} \mathrm{C}$. Sample thickness $300 \mu \mathrm{m}$, long edge corresponds to $2 \mathrm{~mm}$.

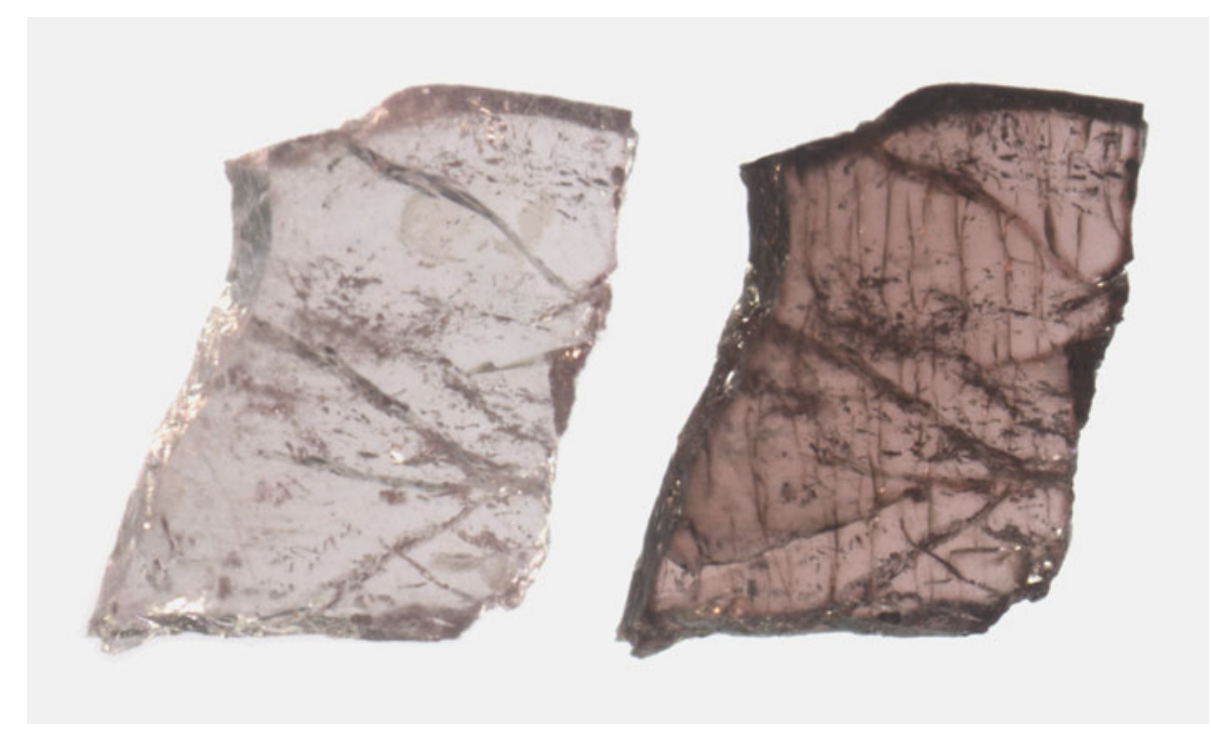

horizontal tube furnace equipped with a quartz-glass tube. The experiments were ended by pushing the sample container out to the cold zone of the quartz tube, which caused the sample to cool to room temperature within one minute. A distinct increase in colour intensity appeared after heat treatment, as shown in Fig. 2. Minor cracks appeared in the thicker sample after treatment at the higher temperature.

\section{Single-crystal structure refinement (SREF)}

A representative crystal fragment of the purplish-red tourmaline from Madagascar was selected for X-ray diffraction measurements on a Bruker KAPPA APEX-II single-crystal diffractometer (Sapienza University of Rome, Earth Sciences Department), equipped with a charge-coupled device (CCD) area detector $(6.2 \mathrm{~cm} \times 6.2 \mathrm{~cm}$ active detection area, $512 \times 512$ pixels $)$ and a graphite-crystal monochromator using MoKa radiation from a fine-focus sealed X-ray tube. The sample-to-detector distance was $4 \mathrm{~cm}$. A total of 3577 exposures ( $\mathrm{step}=0.2^{\circ}$, time $/ \mathrm{step}=20 \mathrm{~s}$ ) covering a full reciprocal sphere with a redundancy of $\sim 12$ was collected. Final unit-cell parameters were refined using the Bruker AXS SAINT program on reflections with $I>10 \sigma(I)$ in the range $5^{\circ}<2 \theta<78^{\circ}$. The intensity data were processed and corrected for Lorentz, polarisation and background effects using the APEX2 software program of Bruker AXS. The data were corrected for absorption using a multi-scan method (SADABS, Bruker AXS). The absorption correction led to an improvement in $R_{\text {int }}$ (from 0.033 to 0.027$)$. No violation of $R 3 m$ symmetry was detected.

Structure refinement was done using the SHELXL-2013 program (Sheldrick, 2015). Starting coordinates were taken from Bosi et al. (2013). Variable parameters were scale factor, extinction coefficient, atom coordinates, site-scattering values (for $X$, $Y$ and $Z$ sites) and atomic-displacement factors. Attempts to refine the extinction coefficient yielded values within its standard uncertainty, thus it was not refined. Neutral scattering factors were used for the cations and oxygen atoms. As for the atomic model refinement and in accordance with the chemical analysis results (see below), the $X$ site was modelled by setting the vacancy content to 0.32 atoms per formula unit (apfu) and allowing the remainder of the site to refine as $\mathrm{Ca}=(0.65-\mathrm{Na})$. Similarly, the $Y$ site was refined by setting the $(\mathrm{Mn}+\mathrm{Fe})$ occupancy to $0.19 \mathrm{apfu}$ and allowing the remainder of the site to refine as
$\mathrm{Al}=(2.81-\mathrm{Li})$ apfu. The $T$ site was modelled by $\mathrm{Si}$ versus $\mathrm{B}$. The $Z, B$ and anion sites were modelled with $\mathrm{Al}, \mathrm{B}$ and $\mathrm{O}$ scattering factors, respectively, and with a fixed occupancy of 1 as refinement with unconstrained occupancies showed no significant deviations from this value. A final refinement was then performed by modelling the site occupancy of the $\mathrm{O} 1$ site with $\mathrm{O}$ and $\mathrm{F}$ fixed to the value obtained from the empirical formula (see below). Similar chemical constraints were applied to refine the $\mathrm{H} 1$ and H3 sites. There were no correlations greater than 0.7 between the parameters at the end of the refinement.

Table 1 lists crystal data, data-collection information and refinement details; Table 2 gives the fractional atom coordinates

Table 1. Single-crystal X-ray diffraction data details for the purplish-red tourmaline from Madagascar.

\begin{tabular}{|c|c|}
\hline \multicolumn{2}{|l|}{ Crystal data } \\
\hline Crystal sizes (mm) & $0.10 \times 0.16 \times 0.18$ \\
\hline Space group; $Z$ & $R 3 m, 3$ \\
\hline$a(\AA)$ & $15.7935(4)$ \\
\hline$c(\AA)$ & $7.0860(2)$ \\
\hline$V\left(\AA^{3}\right)$ & $1530.69(9)$ \\
\hline \multicolumn{2}{|l|}{ Data collection } \\
\hline Data collection temperature $(\mathrm{K})$ & 293 \\
\hline Range for data collection, $2 \theta\left(^{\circ}\right)$ & $5-78$ \\
\hline Radiation, wavelength $(\AA ̊)$ & 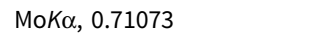 \\
\hline \multirow[t]{3}{*}{ Reciprocal space range, $h k l$} & $-26 \leq h \leq 25$ \\
\hline & $-22 \leq k \leq 24$ \\
\hline & $-12 \leq l \leq 12$ \\
\hline Total number of frames & 3577 \\
\hline Measured reflections & 12,849 \\
\hline Unique reflections, $R_{\text {int }}(\%)$ & $2026,3.03$ \\
\hline Redundancy & 12 \\
\hline Absorption correction method & SADABS \\
\hline \multicolumn{2}{|l|}{ Refinement } \\
\hline Refinement method & Full-matrix last-squares on $F^{2}$ \\
\hline Structural refinement program & SHELXL-2013 \\
\hline Extinction coefficient & $0.0017(3)$ \\
\hline Flack parameter & $0.05(7)$ \\
\hline$w R_{2}(\%)$ & 3.98 \\
\hline$R_{1}(\%)$ all data & 1.89 \\
\hline$R_{1}(\%)$ for $1>2 \sigma(I)$ & 1.80 \\
\hline GooF & 1.020 \\
\hline Largest diff. peak and hole $\left( \pm e^{-} / \AA^{3}\right)$ & -0.45 and 0.35 \\
\hline
\end{tabular}

Notes: $R_{\text {int }}=$ merging residual value; $R_{1}=$ discrepancy index, calculated from $F$-data; $w R_{2}=$ weighted discrepancy index, calculated from $F^{2}$ data; GooF = goodness of fit; Diff. Peaks = maximum and minimum residual electron density. 
Table 2. Fractional atom coordinates, equivalent isotropic and isotropic displacement parameters $\left(\AA^{2}\right)$ and site occupancies for the purplish-red tourmaline from Madagascar.

\begin{tabular}{|c|c|c|c|c|c|}
\hline Site & $x / a$ & $y / b$ & $z / c$ & $U_{\text {eq }}$ & Site occupancy \\
\hline$x$ & 0 & 0 & $0.2208(2)$ & $0.0206(6)$ & $\mathrm{Na}_{0.396(10)} \mathrm{Ca}_{0.259(10)}$ \\
\hline Y & $0.12118(5)$ & $0.06059(2)$ & $0.63828(10)$ & $0.00809(17)$ & $\mathrm{Li}_{0.260(4)} \mathrm{Al}_{0.680(4)} \mathrm{Mn}_{0.0604}$ \\
\hline$Z$ & $0.29680(3)$ & $0.26032(3)$ & $0.60773(7)$ & $0.00650(8)$ & $\mathrm{Al}_{1.00}$ \\
\hline$B$ & $0.10901(7)$ & $0.21802(14)$ & $0.4521(2)$ & $0.0063(3)$ & $\mathrm{B}_{1.00}$ \\
\hline$T$ & $0.19143(2)$ & $0.18954(2)$ & 0 & $0.00515(9)$ & $\mathrm{Si}_{0.916(4)} \mathrm{B}_{0.084(4)}$ \\
\hline $\mathrm{O} 1(\equiv \mathrm{W})$ & 0 & 0 & $0.7750(3)$ & $0.0200(5)$ & $\mathrm{O}_{0.872} \mathrm{~F}_{0.128}$ \\
\hline $\mathrm{O} 2$ & $0.06014(5)$ & $0.12028(10)$ & $0.4891(2)$ & $0.0139(3)$ & $\mathrm{O}_{1.00}$ \\
\hline O3(三V) & $0.26161(11)$ & $0.13080(6)$ & $0.50677(17)$ & $0.0119(2)$ & $\mathrm{O}_{1.00}$ \\
\hline 04 & $0.09391(5)$ & $0.18781(11)$ & $0.07377(18)$ & $0.0107(2)$ & $\mathrm{O}_{1.00}$ \\
\hline $\mathrm{O} 5$ & $0.18629(11)$ & $0.09314(5)$ & $0.09516(17)$ & $0.0109(2)$ & $\mathrm{O}_{1.00}$ \\
\hline 06 & $0.19435(6)$ & $0.18391(6)$ & $0.77405(13)$ & $0.00771(15)$ & $\mathrm{O}_{1.00}$ \\
\hline 07 & $0.28640(6)$ & $0.28591(6)$ & $0.07611(11)$ & $0.00743(15)$ & $\mathrm{O}_{1.00}$ \\
\hline 08 & $0.20947(7)$ & $0.27000(7)$ & $0.43694(13)$ & $0.00766(15)$ & $\mathrm{O}_{1.00}$ \\
\hline $\mathrm{H} 1$ & 0 & 0 & $0.909(4)$ & $0.024^{\mathrm{a}}$ & $\mathrm{H}_{0.5011}$ \\
\hline $\mathrm{H} 3$ & $0.2543(19)$ & $0.1271(9)$ & $0.379(3)$ & $0.014^{\mathrm{a}}$ & $\mathrm{H}_{1.00}$ \\
\hline
\end{tabular}

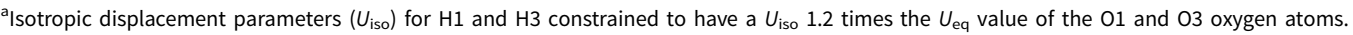

Table 3. Selected bond lengths $(\AA)$ for the purplish-red tourmaline from Madagascar.

\begin{tabular}{|c|c|c|c|c|c|}
\hline$x-02 \times 3$ & $2.5145(18)$ & Z-06 & $1.8737(9)$ & $B-02$ & $1.362(2)$ \\
\hline$x-05 \times 3$ & $2.6989(15)$ & Z-O7 & $1.8816(9)$ & $B-08 \times 2$ & $1.3785(13)$ \\
\hline$x-04 \times 3$ & $2.7720(16)$ & Z-08 & $1.8820(9)$ & $<B-O>$ & 1.373 \\
\hline \multirow[t]{2}{*}{$<X-0>$} & 2.662 & Z-08' & $1.8977(9)$ & & \\
\hline & & Z-O7' & $1.9365(9)$ & $T-07$ & $1.6045(9)$ \\
\hline Y-O1 & $1.9199(14)$ & Z-O3 & $1.9666(7)$ & $T-06$ & $1.6054(9)$ \\
\hline$Y-06 \times 2$ & $1.9503(10)$ & $<Z-O>$ & 1.906 & $T-04$ & $1.6138(5)$ \\
\hline$Y-02 \times 2$ & $1.9605(10)$ & & & T-05 & $1.6295(6)$ \\
\hline$Y-03$ & $2.1349(16)$ & & & $<T-O>$ & 1.613 \\
\hline$<Y-O\rangle$ & 1.979 & & & & \\
\hline
\end{tabular}

and equivalent isotropic displacement parameters; Table 3 shows selected bond lengths. A Supplementary Table with anisotropic displacement parameters and a crystallographic information file have been deposited with the Principal Editor of Mineralogical Magazine and are available as Supplementary material (see below).

\section{Electron microprobe analysis (EMPA)}

Electron microprobe analysis, carried out on the same crystal that was used for the SREF, was performed using a wavelength dispersive spectrometer (WDS mode) with a Cameca SX50 instrument at the Istituto di Geologia Ambientale e Geoingegneria, CNR, Rome, Italy. The following analytical conditions were used: accelerating voltage $15 \mathrm{kV}$, beam current $15 \mathrm{nA}$ and spot diameter $10 \mu \mathrm{m}$. Minerals and synthetic compounds were used as standards: wollastonite $(\mathrm{Si}, \mathrm{Ca})$, magnetite $(\mathrm{Fe})$, rutile $(\mathrm{Ti})$, corundum $(\mathrm{Al})$, vanadinite $(\mathrm{V})$, fluorophlogopite $(\mathrm{F})$, periclase $(\mathrm{Mg})$, jadeite $(\mathrm{Na})$, orthoclase $(\mathrm{K})$, sphalerite $(\mathrm{Zn})$, rhodonite $(\mathrm{Mn})$, metallic $\mathrm{Cr}$ and $\mathrm{Cu}$. The PAP routine was applied (Pouchou and Pichoir, 1991). The results (Table 4) represent mean values of 8 spot analyses. Vanadium, $\mathrm{Cr}, \mathrm{Cu}, \mathrm{Zn}$ and $\mathrm{K}$ were below detection limits $(<0.03$ wt.\%). Chemical analysis is given in Table 4 ; no other elements heavier than $\mathrm{F}$ were detected.

\section{Micro-laser induced breakdown spectroscopy ( $\boldsymbol{\mu}$-LIBS)}

Lithium analysis, carried out on a representative sample fragment, was performed using a double pulse Q-Switched (Nd-YAG, $\lambda=$
Table 4. Chemical composition for the purplish-red tourmaline from Madagascar.

\begin{tabular}{|c|c|c|c|}
\hline \multirow[b]{2}{*}{$\mathrm{SiO}_{2}$ wt. $\%$} & \multirow{2}{*}{$\begin{array}{c}\text { Average of } 8 \text { spots } \\
35.59(35)\end{array}$} & \multicolumn{2}{|c|}{$\begin{array}{c}\text { Atoms normalised to } 31 \\
\text { anions }\end{array}$} \\
\hline & & Si (apfu) & 5.600 \\
\hline $\mathrm{TiO}_{2}$ & $0.04(2)$ & $\mathrm{Ti}^{4+}$ & 0.004 \\
\hline $\mathrm{B}_{2} \mathrm{O}_{3}$ & $12.51^{\mathrm{a}}$ & B & 3.400 \\
\hline $\mathrm{Al}_{2} \mathrm{O}_{3}$ & $42.11(50)$ & $\mathrm{Al}$ & 7.810 \\
\hline $\mathrm{Fe}_{2} \mathrm{O}_{3}$ & $0.31(3)$ & $\mathrm{Fe}^{3+}$ & 0.036 \\
\hline $\mathrm{MnO}_{\text {tot }}$ & $1.09(2)$ & $\mathrm{Mn}^{3+}$ & 0.024 \\
\hline $\mathrm{CaO}$ & $1.43(5)$ & $\mathrm{Mn}^{2+}$ & 0.121 \\
\hline $\mathrm{Na}_{2} \mathrm{O}$ & $1.36(4)$ & $\mathrm{Ca}$ & 0.241 \\
\hline $\mathrm{Li}_{2} \mathrm{O}$ & $1.59(11)^{b}$ & $\mathrm{Na}$ & 0.414 \\
\hline $\mathrm{F}$ & $0.26(8)$ & $\mathrm{Li}$ & 1.004 \\
\hline $\mathrm{H}_{2} \mathrm{O}$ & $3.34^{\mathrm{a}}$ & $\mathrm{F}$ & 0.128 \\
\hline$-\mathrm{O}=\mathrm{F}$ & -0.11 & $\mathrm{OH}$ & 3.501 \\
\hline $\mathrm{MnO}$ & $0.91^{c}$ & & \\
\hline $\mathrm{Mn}_{2} \mathrm{O}_{3}$ & $0.20^{\mathrm{C}}$ & & \\
\hline Total & 99.52 & & \\
\hline
\end{tabular}

${ }^{a}$ Calculated by stoichiometry, $(\mathrm{Y}+\mathrm{Z}+\mathrm{T}+\mathrm{B})=18.000$ apfu.

betermined by $\mu$-LIBS

'Determined by OAS.

Errors for oxides and fluorine are standard deviations (in brackets); apfu = atoms per formula unit.

$1064 \mathrm{~nm}$ ) laser with a $1 \mu$ s delay between the two pulses with an energy of $110 \mathrm{~mJ}$ per pulse. The small spot size $(7-10 \mu \mathrm{m})$ was obtained using a petrographic optical microscope (objective lens 10X NA 0.25 WD $14.75 \mathrm{~mm}$ ). The LIBS spectra were acquired by an AvaSpec Fiber Optic Spectrometer (390-900 nm with $0.3 \mathrm{~nm}$ resolution) with a delay of $2 \mu \mathrm{s}$ after the second pulse and an integration time of $1 \mathrm{~ms}$.

The main problem regarding Li quantification by LIBS concerns the self-absorption of the emission line used to extract quantitative data. In the present tourmaline, the quantitative data were obtained from linear regression using the main Li emission line intensity $\left(I_{\mathrm{Li}}=670.706 \mathrm{~nm}\right.$, corresponding to the resonance transition $1 s^{2} 2 s>1 s^{2} 2 p$ ) in the range from 0.009 to 2.04 wt.\% of $\mathrm{Li}_{2} \mathrm{O}$. In this regard, we verified that the selfabsorption effect of this specific line was negligible in the studied concentration range, hence, not affecting the measurements. This is consistent with previous studies on beryl (McMillan et al., 2006; Tempesta and Agrosì, 2016; Tempesta et al., 2020). Moreover, the 


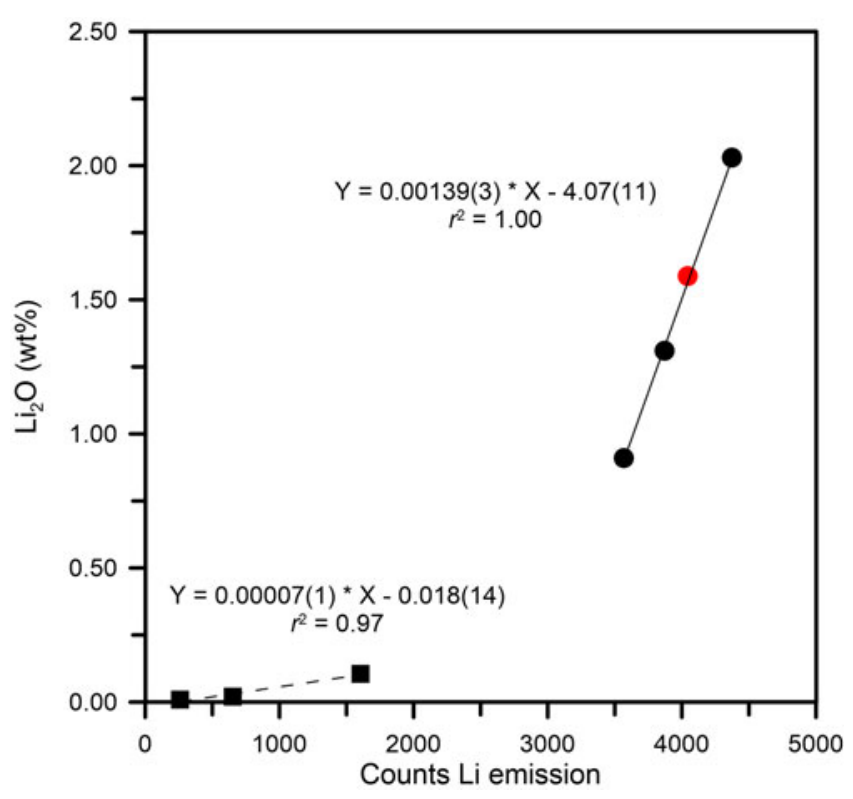

Fig. 3. Calibration of the Li emission line at $670.7 \mathrm{~nm}$. The calibration resulted in two branches (one below and the other above $0.1 \mathrm{Li}_{2} \mathrm{O}$ wt.\%) described by two regression lines. Black squares represent samples from NIST standard glasses (SRM 610 and 612) and Filip et al. (2012), black circles are from Bosi et al. (2005, 2019d) and Grew et al. (2018); and a red filled circle represents the present sample.

low variability of counts, verified by measurements on uniform matrix materials such as that of NIST glass samples, allowed us to perform measurements on tourmaline samples which normally have chemical zoning. The calibration, obtained using spectra recorded on two NIST standard glasses (SRM 610 and 612) and four Li-bearing tourmalines from Bosi et al. (2005), Filip et al. (2012), Grew et al. (2018) and Bosi et al. (2019d), resulted in two calibration curves: one below and the other above $0.1 \mathrm{Li}_{2} \mathrm{O}$ wt.\% (Fig. 3). The latter was used for the present sample to obtain the $\mathrm{Li}$ quantification from the linear fit equation: $\mathrm{Li}_{2} \mathrm{O}=0.00139(3) \cdot I_{\mathrm{Li}}-4.07(11)$. The result corresponds to 1.59 (11) wt.\% of $\mathrm{Li}_{2} \mathrm{O}$ (Table 4 ).

It can be noted that $\mu$-LIBS represents a very proficient localised analytical method, in particular if LIBS is mounted to a microscope to achieve a micrometric scale resolution. The intense emissivity of $\mathrm{Li}$ in optical emission spectroscopy makes the LIBS technique advantageous for $\mathrm{Li}$ quantification. Moreover, the potential of LIBS for Li analysis of geological materials at the micrometric scale has been validated in previous studies (Fabre et al., 2002; Sweetapple and Tassios, 2015; McMillan et al., 2018).

\section{Micro-Raman spectroscopy}

Raman spectra of the $\mathrm{Mn}^{3+}$-bearing red tourmaline were obtained using a micro/macro Jobin Yvon Mod. LabRam HRVIS (University of Turin, Interdepartmental Centre "G. Scansetti"), equipped with a motorised $x-y$ stage and an Olympus microscope. The back-scattered Raman signal was collected with a $50 \times$ objective and the Raman spectrum was obtained for a $90^{\circ}$ (perpendicular to c) oriented crystal. The $632.8 \mathrm{~nm}$ line of an He-Ne laser was used as excitation; laser power $(20 \mathrm{~mW})$ was controlled by means of a series of density filters. The minimum lateral and depth resolution was set to a few $\mu \mathrm{m}$. The system was calibrated using the $520.6 \mathrm{~cm}^{-1}$ Raman band of silicon before each experimental session. The spectra were collected with a multiple and repeated acquisition (5) with single counting times of 50 seconds to improve the signal-to-noise ratio. The incident excitation light was scrambled to eliminate orientation and polarisation effects. The spectrum was recorded from 100 to $4000 \mathrm{~cm}^{-1}$ using the LabSpec 5 software package (Horiba Jobin Yvon GmbH, 2004, 2005). Band-component analysis was undertaken using a Lorentzian function (Fityk software package; Wojdyr, 2010). The intensity of the vibrational modes was proven to be very dependent on the polarisability tensor. The Raman spectrum of the present sample in the spectral region of the framework and $(\mathrm{OH})$-stretching vibrations is shown in Fig. 4.

\section{Fourier-transform infrared (FTIR) spectroscopy}

Polarised Fourier-transform infrared spectra were measured on two doubly polished single-crystal sections oriented by means of optical microscopy, and with thicknesses of 55 and $309 \mu \mathrm{m}$. The spectrometer system consisted of a Bruker Vertex $70 \mathrm{spec}-$ trometer equipped with a halogen-lamp source and a $\mathrm{CaF}_{2}$ beam-splitter coupled to a Hyperion 2000 microscope with a ZnSe wire-grid polariser and an InSb detector. Spectra were measured before and after heat-treatment experiments over the wavenumber range $2000-15,000 \mathrm{~cm}^{-1}$ with a resolution of 2 or $8 \mathrm{~cm}^{-1}$. The measuring areas were masked by a $50-100 \mu \mathrm{m}$ rectangular aperture to avoid cracks and inclusions. The FTIR spectra of the untreated and treated samples (e.g. Fig. 5) show typical, strongly pleochroic absorption bands in the $(\mathrm{OH})$-stretching region $\left(3300-3800 \mathrm{~cm}^{-1}\right)$, including bands above $\sim 3600 \mathrm{~cm}^{-1}$ that demonstrate the presence of ${ }^{\mathrm{W}}(\mathrm{OH})$ (see below).

\section{Optical absorption spectroscopy (OAS)}

Polarised, room temperature optical absorption spectra in the range $30,000-12,500 \mathrm{~cm}^{-1}(333-800 \mathrm{~nm})$ were recorded at a spectral resolution of $1 \mathrm{~nm}$ on the same $309 \mu \mathrm{m}$ thick section studied by FTIR spectroscopy, using an AVASPEC-ULS2048 × 16 spectrometer attached via a $400 \mu \mathrm{m}$ ultraviolet (UV) optical fibre cable to a Zeiss Axiotron UV-microscope. A $75 \mathrm{~W}$ Xenon arc lamp was used as a light source, and Zeiss Ultrafluar $10 \times$ lenses served as objective and condenser. The diameter of the circular aperture was $50 \mu \mathrm{m}$ for the untreated sample and $30 \mu \mathrm{m}$ for the treated sample. A UV-quality Glan-Thompson prism with a working range from 40,000 to $3704 \mathrm{~cm}^{-1}$ (250 to $2700 \mathrm{~nm}$ ) was used as a polariser. The wavelength scale of the spectrometer was calibrated against $\mathrm{Ho}_{2} \mathrm{O}_{3}$-doped and $\mathrm{Pr}_{2} \mathrm{O}_{3} / \mathrm{Nd}_{2} \mathrm{O}_{3}$-doped standards (Hellma glass filters 666F1 and 666F7). Spectral data in the range $12,150-2000 \mathrm{~cm}^{-1}(800-5000 \mathrm{~nm})$ was taken from the FTIR measurements.

The optical absorption spectra of the untreated sample (Fig. 6) at energies below the UV-absorption edge show a set of broad absorption bands at 21,950,19,800, 18,000,13,500 and $\sim 9500 \mathrm{~cm}^{-1}$ (corresponding to $456,505,556,741$ and $1053 \mathrm{~nm}$ ). In addition, a very weak and sharp absorption band occurs at $24,330 \mathrm{~cm}^{-1}$ $(418 \mathrm{~nm})$, and a set of very sharp, overlapping bands are recorded in the NIR spectral range between $6700-7200 \mathrm{~cm}^{-1}(1492-1389 \mathrm{~nm})$. The absorption bands recorded in spectra of the untreated sample at $24,330,21,950$ and $\sim 18,000 \mathrm{~cm}^{-1}$ are more intense for light polarised perpendicular to the crystallographic c-axis. Conversely, the absorption band $19800 \mathrm{~cm}^{-1}$ is only observed as a broad shoulder in the $\mathbf{E} \| \mathbf{c}$-spectrum. The set of sharp bands between $6700-7200 \mathrm{~cm}^{-1}$ is also completely E || $\mathbf{c}$-polarised. 


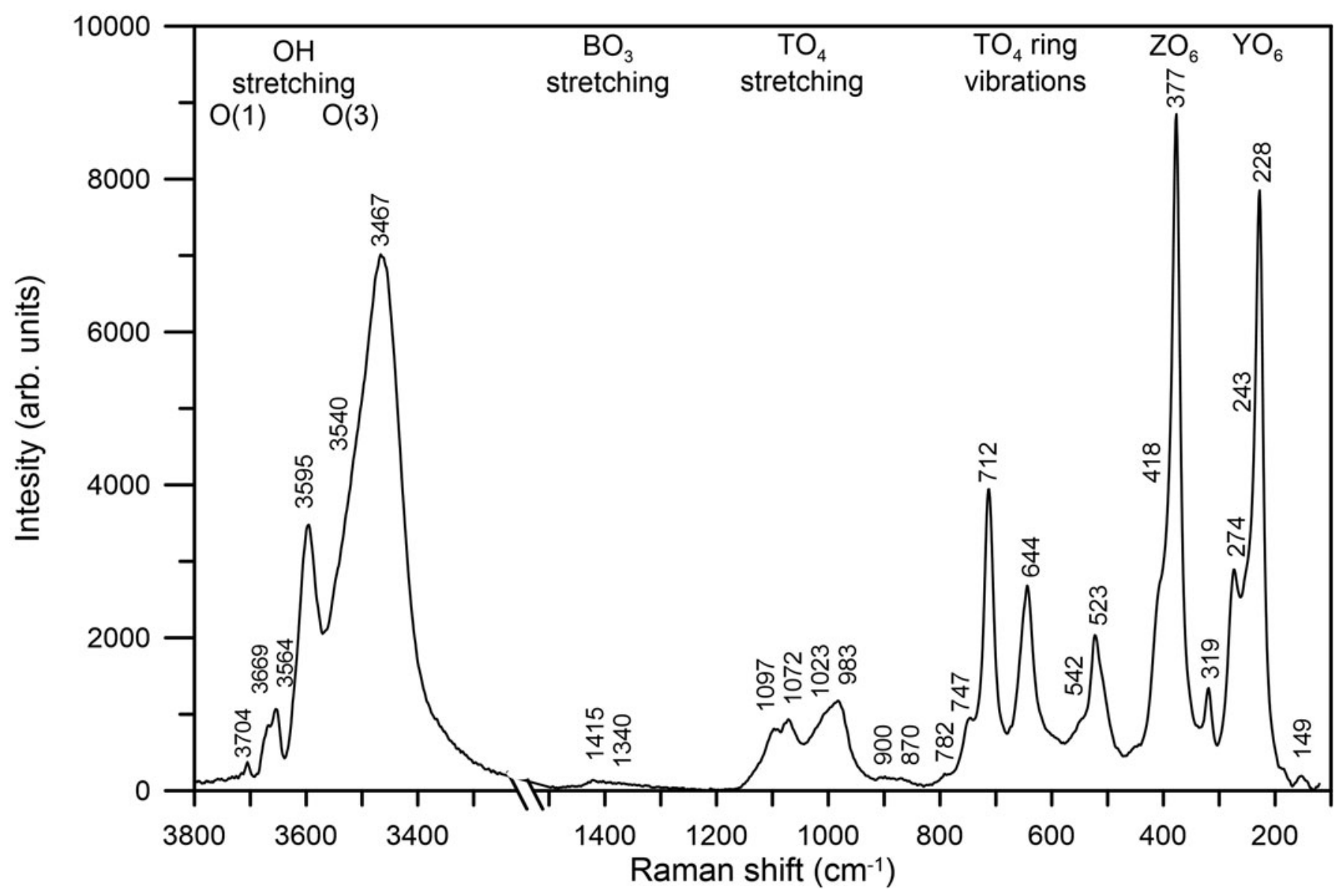

Fig. 4. Raman spectrum of the untreated Mn-bearing purplish-red tourmaline from Madagascar.

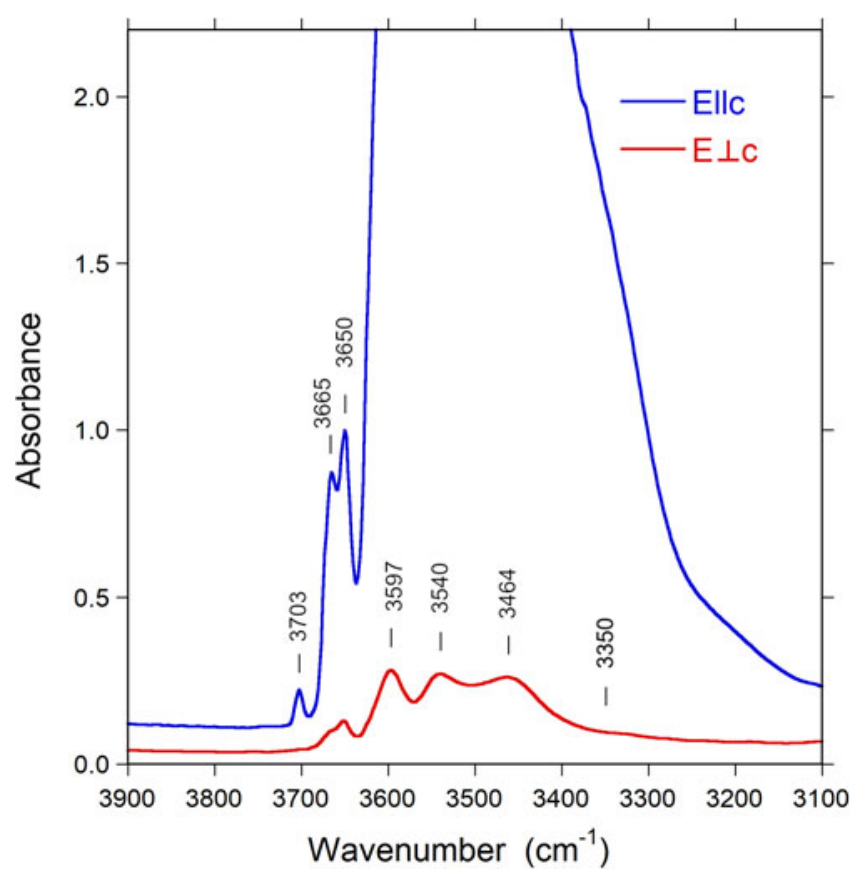

Fig. 5. Polarised FTIR spectra $(\mathbf{E} \| \mathbf{c}$ and $\mathbf{E} \perp \mathbf{c}$ ) of untreated Mn-bearing purplish-red tourmaline from Madagascar. Sample thickness $55 \mu \mathrm{m}$. Spectra are vertically off-set for clarity. Peak positions are indicated.

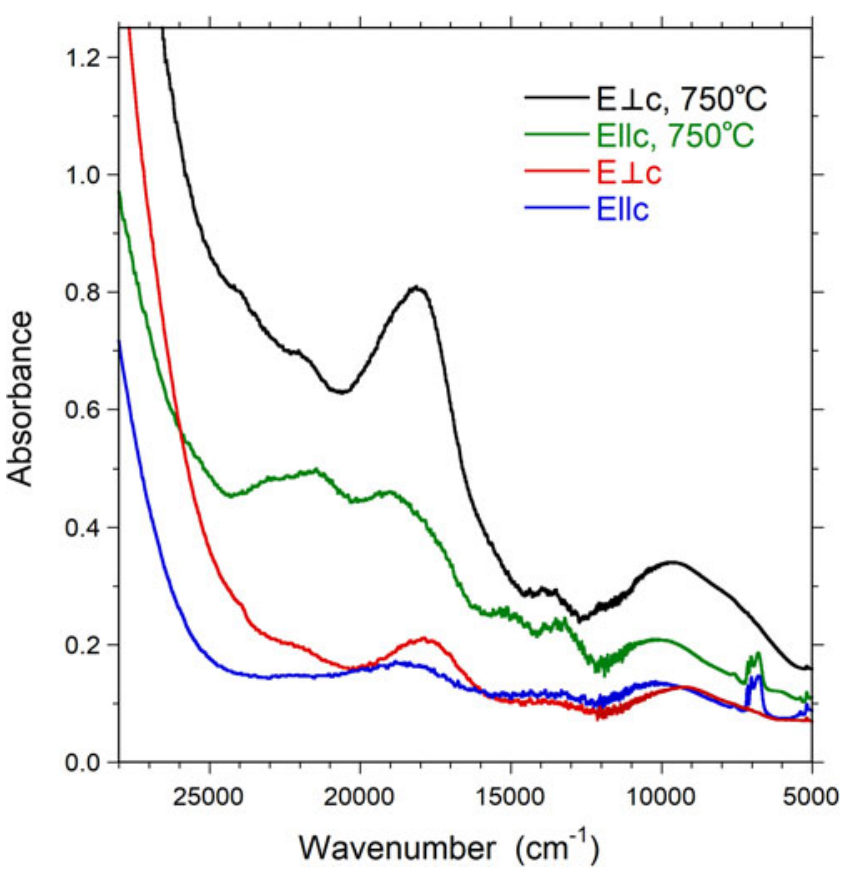

Fig. 6. Polarised OAS spectra $(\mathbf{E} \| \mathbf{c}$ and $\mathbf{E} \perp \mathbf{c})$ of untreated and treated $M n$-bearing purplish-red tourmaline from Madagascar. Sample thickness $309 \mu \mathrm{m}$. Spectra are vertically off-set for clarity. 
The absorption spectra recorded on the heat-treated sample (Fig. 6) display comparable features to those observed in the spectra of the natural sample. However, all absorption bands at 21,950, $19,800, \sim 18,000,13,500$ and $\sim 9500 \mathrm{~cm}^{-1}$ show pronounced intensity gains, and the set of sharp absorption bands between 6700 $7200 \mathrm{~cm}^{-1}$ distinctly decreases in intensity.

\section{Determination of atomic fractions}

For the untreated sample, manganese oxidation state was determined by OAS (see below and Table 4). All Fe was considered to be $\mathrm{Fe}^{3+}$ based on the OAS results and $\mathrm{Mn}$ and $\mathrm{Fe}$ redox potential arguments. Lithium was determined by $\mu$-LIBS. Regarding the $\mathrm{B}^{3+}$, the SREF data indicate that it fully occupies the $B$ site, but relatively small amounts of $\mathrm{B}^{3+}$ also occur at the $T$ site: $T$-m.a.n. $=13.24(7)$ and $\langle T-\mathrm{O}\rangle=1.613 \AA$ are in fact significantly smaller than the expected value for a $T$ site fully occupied by $\mathrm{Si}$ $\left({ }^{T}\right.$ Si-m.a.n. $=14$ and $\left\langle{ }^{T} \mathrm{Si}-\mathrm{O}\right\rangle=1.619 \pm 0.001 \AA ; \quad$ Bosi and Lucchesi, 2007), reflecting the presence of cations lighter and smaller than $\mathrm{Si}$, such as $\mathrm{B}^{3+}$ (Ertl et al., 2018). As a result, the $\mathrm{B}_{2} \mathrm{O}_{3}$ and $(\mathrm{OH})$ content were calculated by charge balance with the assumption $(\mathrm{T}+\mathrm{Y}+\mathrm{Z}+\mathrm{B})=18.00$ apfu and 31 anions.

For the heat-treated sample, all $\mathrm{Mn}$ was considered as $\mathrm{Mn}^{3+}$ (i.e. $\mathrm{Mn}_{2} \mathrm{O}_{3}=1.21$ wt.\%), in conformity with the heat treatment conditions and the redox reaction:

$$
\left(\mathrm{Mn}^{2+}\right)+(\mathrm{OH})^{-} \rightarrow\left(\mathrm{Mn}^{3+}\right)+\left(\mathrm{O}^{2-}\right)+1 / 2 \mathrm{H}_{2}(\mathrm{~g})
$$

\section{Determination of site population and mineral formula}

The anion site populations in the samples studied follow the general preference suggested for tourmaline (e.g. Henry et al., 2011): the $\mathrm{O} 3$ site (V position in the general formula) is occupied by $(\mathrm{OH})^{-}$, while the $\mathrm{O} 1$ site (W position in the general formula) can be occupied by $\mathrm{O}^{2-},(\mathrm{OH})^{-}$and $\mathrm{F}^{-}$. The refined $Z$-site scattering and $\langle Z-\mathrm{O}\rangle$ values ( 13 and $1.906 \AA$, respectively) are the typical values observed for a $Z$ site fully occupied by $\mathrm{Al}$ (Bosi and Andreozzi, 2013). The resulting empirical formula for the untreated sample is as follows:

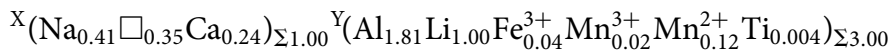

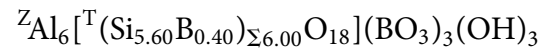

$$
\begin{aligned}
& { }^{\mathrm{W}}\left[(\mathrm{OH})_{0.50} \mathrm{~F}_{0.13} \mathrm{O}_{0.37}\right]_{\Sigma 1.00}
\end{aligned}
$$

The bond-valence analysis is consistent with the proposed site populations (Table 5). Moreover, the amount of $0.40{ }^{\mathrm{T}} \mathrm{B}^{3+}$ apfu is consistent with the relation of Hughes et al. $(2004):{ }^{[4]} \mathrm{B}=$ $\left[53.404-0.0346 \cdot V_{\text {cell }}\right]=0.44$ apfu.

As for the treated sample, the following ordered formula is proposed:

$$
\begin{aligned}
& { }^{\mathrm{X}}\left(\mathrm{Na}_{0.41} \square_{0.35} \mathrm{Ca}_{0.24}\right)_{\Sigma 1.00}{ }^{\mathrm{Y}}\left(\mathrm{Al}_{1.81} \mathrm{Li}_{1.00} \mathrm{Fe}_{0.04}^{3+} \mathrm{Mn}_{0.15}^{3+} \mathrm{Ti}_{0.004}\right)_{\Sigma 3.00}
\end{aligned}
$$

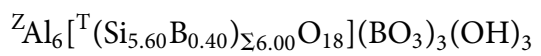

$$
\begin{aligned}
& \left.\left.\mathrm{W}_{[(\mathrm{OH})}\right)_{0.38} \mathrm{~F}_{0.13} \mathrm{O}_{0.49}\right]_{\Sigma 1.00}
\end{aligned}
$$

\section{Discussion}

\section{Tourmaline classification}

The empirical formula of the untreated sample is consistent with a tourmaline belonging to the alkali-group, subgroup 2 (Henry et al., 2011): it is Na-dominant ( $\mathrm{Na}>\square>\mathrm{Ca}$ ) at the $\mathrm{X}$ position
Table 5. Weighted bond valences (valence units) for the purplish-red tourmaline from Madagascar.

\begin{tabular}{lllllll}
\hline Site & $X$ & $Y$ & $Z$ & $T$ & $B$ & SUM \\
\hline O1 & & $0.42^{\times 3} \rightarrow$ & & & & 1.25 \\
O2 & $0.12^{\times 3} \downarrow$ & $0.39^{\times 2} \downarrow \rightarrow$ & & & 1.02 & 1.91 \\
O3 & & 0.24 & $0.43^{\times 2} \rightarrow$ & & & 1.09 \\
O4 & $0.06^{\times 3} \downarrow$ & & & $0.99^{\times 2} \rightarrow$ & & 2.04 \\
O5 & $0.07^{\times 3} \downarrow$ & & & $0.95^{\times 2} \rightarrow$ & & 1.97 \\
O6 & & $0.40^{\times 2} \downarrow$ & 0.55 & 1.01 & & 1.96 \\
O7 & & & 0.54 & 1.01 & & 2.01 \\
& & & 0.46 & & $0.98^{\times 2} \downarrow$ & 2.03 \\
O8 & & & 0.51 & & & \\
& & & 0.54 & & & \\
\hline SUM & 0.73 & 2.24 & 3.02 & 3.96 & 2.98 & \\
MAV $^{\text {a }}$ & 0.90 & 2.29 & 3.00 & 3.93 & 3.00 & \\
\hline
\end{tabular}

Note: Weighted bond valence according to Bosi (2014). Bond valence parameters from Brown and Altermatt (1985).

${ }^{a}$ Expected mean atomic valence (or formal charge) from the empirical formula.

of the general formula of tourmaline $\mathrm{XY}_{3} \mathrm{Z}_{6} \mathrm{~T}_{6} \mathrm{O}_{18}\left(\mathrm{BO}_{3}\right)_{3} \mathrm{~V}_{3} \mathrm{~W}$ and hydroxy-dominant at $\mathrm{W}$ with $(\mathrm{OH}+\mathrm{F})>\mathrm{O}$ and $(\mathrm{OH})>>$ F. Because $\mathrm{Al}$ and $\mathrm{Si}$ are the dominant cations at the $Z$ and $T$ sites (respectively), the end-member formula can be approxi-

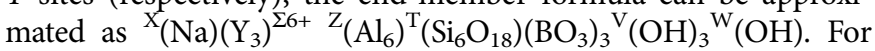
formula electroneutrality reasons, the valency-imposed double site-occupancy for the $Y$ site is required with an atomic arrangement $\left(\mathrm{Li}_{1.5} \mathrm{Al}_{1.5}\right)^{\Sigma 6+}$. In accordance with the tourmaline nomenclature and the IMA-CNMNC rules (Henry et al., 2011; Bosi et al., 2019a,b), the present sample can be classified as Mn-bearing elbaite, $\mathrm{Na}\left(\mathrm{Li}_{1.5} \mathrm{Al}_{1.5}\right) \mathrm{Al}_{6} \mathrm{Si}_{6} \mathrm{O}_{18}\left(\mathrm{BO}_{3}\right)_{3}(\mathrm{OH})_{3} \mathrm{OH}$.

Note that, although the empirical site-total-charge at $\mathrm{Y}$ $(=+6.986)$ is very close to +7 , suggesting the arrangement $\mathrm{Y}_{(}\left(\mathrm{Al}_{2} \mathrm{Li}\right)^{\Sigma 7+}$, the latter must be ruled out because it would lead to a charge imbalanced end-member formula: $\left[\mathrm{Na}\left(\mathrm{Al}_{2} \mathrm{Li}\right)\right.$ $\left.\mathrm{Al}_{6}\left(\mathrm{Si}_{6} \mathrm{O}_{18}\right)\left(\mathrm{BO}_{3}\right)_{3}(\mathrm{OH})_{3} \mathrm{OH}\right]^{\Sigma 1+}$. Thus, only atomic arrangements consistent with $\left(\mathrm{Y}_{3}\right)^{\Sigma 6+}$, such as $\left(\mathrm{Al}_{1.5} \mathrm{Li}_{1.5}\right)^{\Sigma 6+}$, can occur (Bosi et al., 2019a,b).

\section{Micro-Raman spectroscopy in the framework vibration region}

In accordance with the studies of Mihailova et al. (1996), Reddy et al. (2007), McKeown (2008) and Watenphul et al. (2016b), five main ranges of framework vibrations can be identified in the Raman spectrum of the untreated sample (Fig. 4) and attributed to the following vibrating groups. (1) The range $\sim 200-300 \mathrm{~cm}^{-1}$ is dominated by $\mathrm{YO}_{6}$ vibrations; in particular, the band at $\sim 274 \mathrm{~cm}^{-1}$ corresponds to the $\mathrm{Mn}-\mathrm{O}$ bond, previously observed in a pink-tourmaline by Reddy et al. (2007). (2) The range $\sim 300-400 \mathrm{~cm}^{-1}$ (the strongest Raman peak) is generated by $\mathrm{ZO}_{6}$ vibrations, in particular the sharp peak at $377 \mathrm{~cm}^{-1}$ may be given by the ${ }^{\mathrm{Z}} \mathrm{Al}-\mathrm{O}$ bond. (3) The range $\sim 500-750 \mathrm{~cm}^{-1}$ is dominated by breathing modes of bridging oxygen atoms of $\mathrm{TO}_{4}$ rings. (4) The range $\sim 950-1100 \mathrm{~cm}^{-1}$ is generated mainly from $\mathrm{TO}_{4}$ stretching vibrations. (5) The range $\sim 1300-1400 \mathrm{~cm}^{-1}$ arises from $\mathrm{B}-\mathrm{O}$ stretching vibrations.

With regard to the region of the $(\mathrm{OH})$-stretching vibrations $\left(3300-3800 \mathrm{~cm}^{-1}\right)$, the Raman scattering peaks of the untreated sample show wavenumbers similar to those of the infrared absorption bands (cf. Fig. 4 with Fig. 5); thus, the $(\mathrm{OH})$-stretching modes are discussed below. 


\section{FTIR spectra in the (OH)-stretching region and band assignment}

Infrared spectra of the untreated and treated samples recorded in polarised mode parallel to the c-axis direction display a very intense absorption feature in the $3400-3600 \mathrm{~cm}^{-1}$ region, which is truncated due to excessive absorption (Fig. 5). This problem is commonly encountered in polarised transmission spectra of tourmaline single crystals, and it is normally not possible to thin samples sufficiently to get this main band 'on scale'. Bands of lower intensity occur on both the low-energy (ca. $3340 \mathrm{~cm}^{-1}$ ) and high-energy $\left(3650,3665\right.$ and $3703 \mathrm{~cm}^{-1}$ ) sides of the major absorption band. Spectra polarised perpendicular to the c-axis direction $(\mathbf{E} \perp \mathbf{c})$ show a set of bands with substantially lower intensities (Fig. 5). The spectral range that is obscured by excessive absorption in the $\mathbf{E} \| \mathbf{c}$ direction displays here the presence of three bands at wavenumbers 3464,3540 and $3597 \mathrm{~cm}^{-1}$, indicating $(\mathrm{OH})$-dipoles aligned close to, but with a small inclination to the c-axis (Gatta et al., 2014).

After thermal treatment, a number of changes can be observed in the FTIR spectra: the sharp band at $3665 \mathrm{~cm}^{-1}$ progressively decreases in intensity and almost disappears in the $\mathbf{E} \| \mathbf{c}$ direction (Fig. 7), whereas a new band appears at $3395 \mathrm{~cm}^{-1}$, visible in the $\mathrm{E} \perp \mathbf{c}$ direction (Fig. 8). The $(\mathrm{OH})$ bands in the overtone region (Fig. 9) show a distinct decrease in absorption intensity, amounting to $17 \pm 3 \%$ as estimated from spectral fitting. However, a general decrease in absorption band intensity is not observed in the principal $(\mathrm{OH})$-region in spectra of the heat-treated samples polarised in the $\mathbf{E} \perp \mathbf{c}$ direction. Instead, we observe a weak increase in intensity, probably related to a decrease in polarisation efficiency due to microcracks and other crystal imperfections formed during heat treatment, leading to minor contributions from the extremely intense absorbance in the $\mathbf{E}|| \mathbf{c}$ direction.

In the tourmaline structure, the $\mathrm{O} 1$ site $(\equiv \mathrm{W})$ is surrounded by three $Y$ cations, whereas the $\mathrm{O} 3$ site $(\equiv \mathrm{V})$ is surrounded by

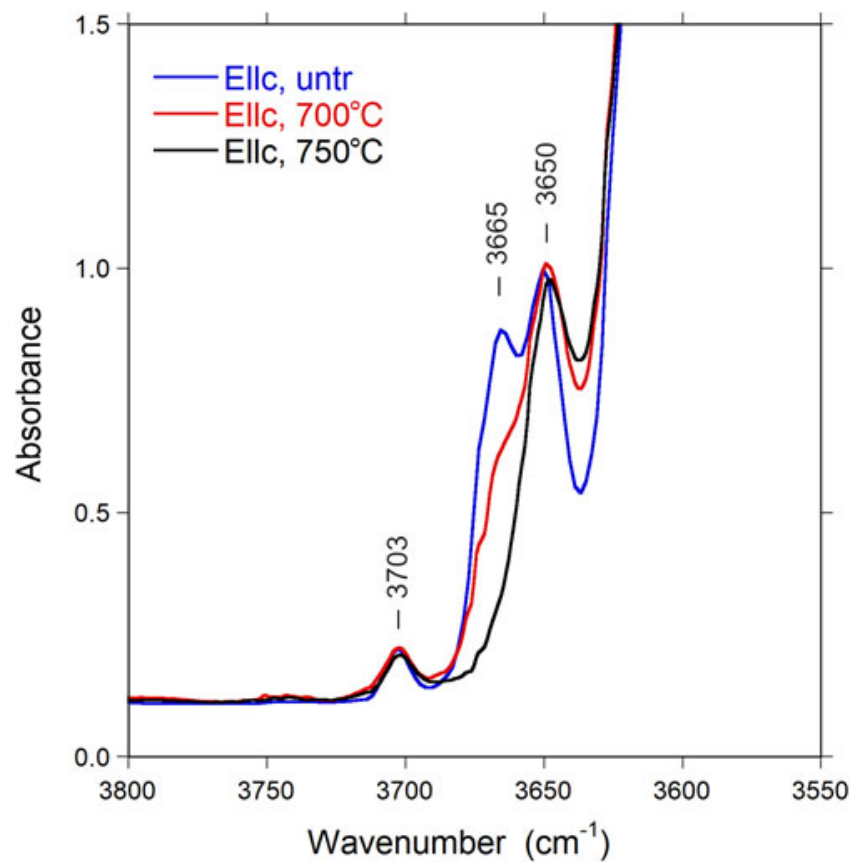

Fig. 7. Polarised FTIR spectra $(\mathbf{E} \| \mathbf{c})$ of untreated and heat-treated Mn-bearing tourmaline. Sample thickness $55 \mu \mathrm{m}$. Spectra are vertically off-set for clarity. Peak positions are indicated.

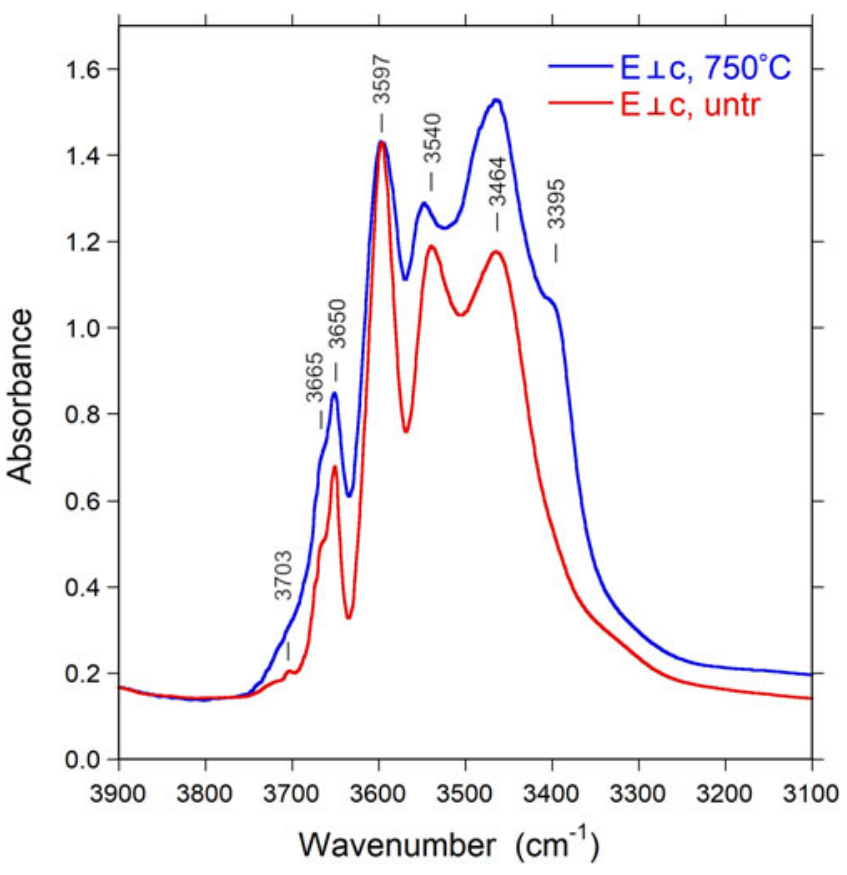

Fig. 8. Polarised FTIR spectra $(\mathbf{E} \perp \mathbf{c})$ of untreated Mn-bearing tourmaline. Sample thickness $309 \mu \mathrm{m}$. Spectra are vertically off-set for clarity. Peak positions are indicated. Note new band appearing at $3395 \mathrm{~cm}^{-1}$ after treatment.

one $Y$ and two $Z$ cations. In accord with Gatta et al. (2014), we assume that: the ${ }^{\mathrm{O}}(\mathrm{OH})$ group forms a very weak hydrogen bond (bond strength $<0.05$ valence units, vu) with $\mathrm{O} 4$ and $\mathrm{O} 5$, whereas the ${ }^{\mathrm{O} 3}(\mathrm{OH})$ group forms a weak hydrogen bond (bond strength $\sim 0.11 \mathrm{vu})$ with the closest $\mathrm{O} 5$ atom $(\mathrm{O} 3-\mathrm{H} 3 \cdots \mathrm{O} 5)$; the strength of the hydrogen bond will cause a frequency shift of

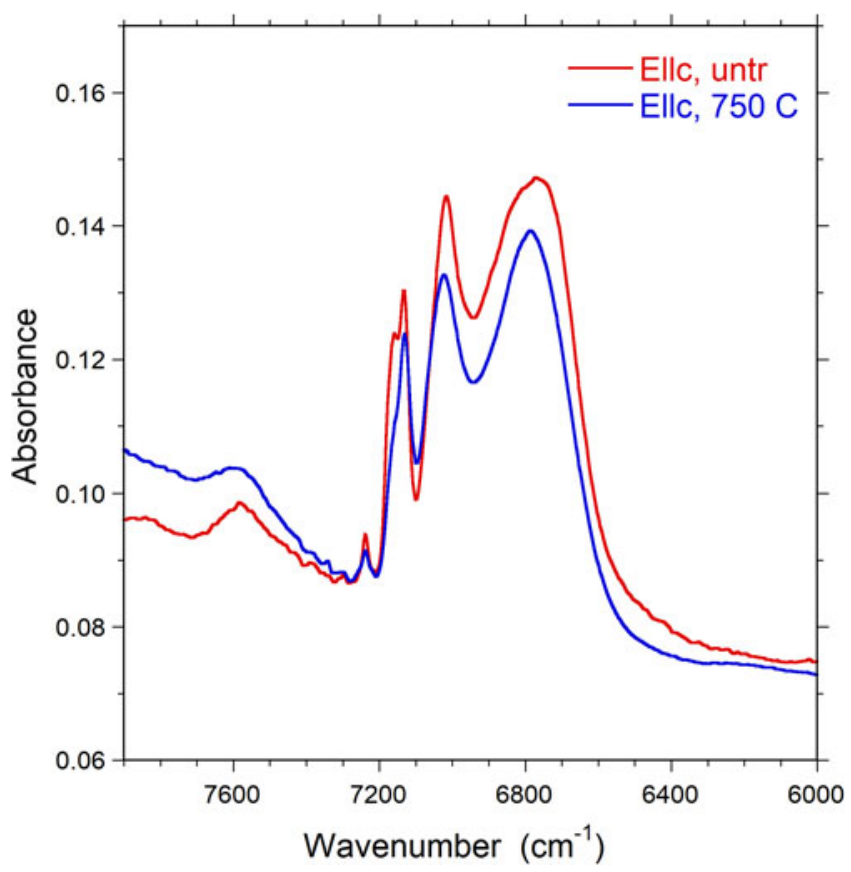

Fig. 9. Polarised FTIR/NIR spectra (E $\mid \mathbf{c}$ ) of untreated and heat-treated Mn-bearing tourmaline in the $\mathrm{OH}$-overtone region. Sample thickness $309 \mu \mathrm{m}$. Spectra are vertically adjusted for clarity. 
the principal (OH)-stretching vibration (e.g. Libowitzky, 1999). Therefore, the relative weak vibrational bands above $\sim 3600 \mathrm{~cm}^{-1}$ may be assigned to the $\mathrm{O} 1$ site, whereas the strong bands below $\sim 3600 \mathrm{~cm}^{-1}$ may be assigned to the O3 site (e.g. Gonzalez-Carreño et al., 1988; Bosi et al., 2015). Based on the studies of Skogby et al. (2012), Bosi et al. (2012, 2016b), Watenphul et al. (2016a) and Kutzschbach et al. (2016) as well as on the observed site populations, the FTIR bands of the present purplish-red tourmaline may be related to the following atomic arrangements:

$\sim 3350 \mathrm{~cm}^{-1}$ is assigned to hydrogen bond ${ }^{\mathrm{O} 3} \mathrm{O}-\mathrm{H} 3 \cdots \mathrm{O} 5$, which may reflect both the presence of ${ }^{T} \mathrm{~B}^{3+}$ and the $X$-site occupancy; $\sim 3395 \mathrm{~cm}^{-1}$ is assigned to $3\left[{ }^{Y}\left(\mathrm{Mn}^{3+}, \mathrm{Al}^{Z} \mathrm{Al}^{Z} \mathrm{Al}\right]-{ }^{\mathrm{O} 3}(\mathrm{OH})_{3}\right.$; $\sim 3464,3540$ and $3597 \mathrm{~cm}^{-1}$ to $3\left[{ }^{Y}\left(\mathrm{Li}, \mathrm{Mn}^{2+}, \mathrm{Al}\right)^{Z} \mathrm{Al}^{Z} \mathrm{Al}\right]-{ }^{\mathrm{O}}(\mathrm{OH})_{3}$; $\sim 3650 \mathrm{~cm}^{-1}$ is assigned to ${ }^{Y}(\mathrm{LiAlAl}){ }^{\mathrm{O} 1}(\mathrm{OH}){ }^{X}(\square)$;

$\sim 3665 \mathrm{~cm}^{-1}$ is assigned to ${ }^{Y}\left(\mathrm{LiMn}^{2+} \mathrm{Al}\right)-{ }^{\mathrm{O} 1}(\mathrm{OH})-{ }^{X}(\square)$; and $\sim 3703 \mathrm{~cm}^{-1}$ is assigned to ${ }^{Y}(\mathrm{LiAlAl})-{ }^{\mathrm{O} 1}(\mathrm{OH})-{ }^{X}(\mathrm{Na})$.

The main difference between the FTIR spectra of the untreated and treated sample occurs in gradual decrease in the intensity of the band at $3665 \mathrm{~cm}^{-1}$ and the appearance of the band at $3395 \mathrm{~cm}^{-1}$ with the increase in temperature up to $750^{\circ} \mathrm{C}$. As a result, these bands, in particular that at $3665 \mathrm{~cm}^{-1}$, may be correlated directly with the decreased $\mathrm{Mn}^{2+}$ and increased $\mathrm{Mn}^{3+}$ content, according to the redox reaction (1), reported in the section 'Determination of atomic fractions'. However, it appears that $(\mathrm{OH})$ is also lost by mechanisms other than the redox reaction. Only a partial loss of $0.12(\mathrm{OH})$ apfu can be coupled to the oxidation of $\mathrm{Mn}^{2+}$, whereas the total $(\mathrm{OH})$ loss as estimated from the decrease of $(\mathrm{OH})$ overtone intensities $(17 \pm 3 \%)$ corresponds to ca. $0.6(\mathrm{OH})$ apfu. The reason for this additional dehydration is unknown, but may be related to initial breakdown processes of the crystal structure.

Of particular interest is also the association of the ${ }^{\mathrm{O} 1}(\mathrm{OH})$ stretching modes with the $X$-site constituents: the bands between $\sim 3600-3700 \mathrm{~cm}^{-1}$ are considered associated with $\mathrm{X}_{\square}$, whereas those above $3700 \mathrm{~cm}^{-1}$ are considered associated with ${ }^{\mathrm{X}} \mathrm{Na}^{+}$. This distinction is related to the repulsive electrostatic interaction between the $\mathrm{X}^{n+}$ cation and $\mathrm{H}^{+}$of the ${ }^{\mathrm{O} 1}(\mathrm{OH})$ group, which reinforces the strength of the ${ }^{\mathrm{O} 1} \mathrm{O}-\mathrm{H}$ bond, shifting the $(\mathrm{OH})$-stretching mode towards higher wavenumbers (e.g. Gonzalez-Carreño et al., 1988; Berryman et al., 2016; Watenphul et al., 2016a). Consequently, the presence of ${ }^{X} \mathrm{Na}^{+}$determines an electrostatic repulsion with ${ }^{\mathrm{H} 1} \mathrm{H}^{+}$along the crystallographic c-axis, whereas the substitution ${ }^{\mathrm{X}} \square \rightarrow{ }^{\mathrm{X}} \mathrm{Na}^{+}$removes such a repulsion (Fig. 10). From the energetic-stability viewpoint, the rossmanite type arrangements $(Y Y Y)-{ }^{\mathrm{O} 1}(\mathrm{OH})-{ }^{X}(\square)$ should hence be more likely to occur than the elbaite type arrangement $(Y Y Y){ }^{\mathrm{O} 1}(\mathrm{OH})-{ }^{X}(\mathrm{Na})$. The $\mathrm{X}^{n+}-\mathrm{H}^{+}$repulsion effect will be stronger with the substitution ${ }^{\mathrm{X}} \mathrm{Ca}^{2+} \rightarrow{ }^{\mathrm{X}} \mathrm{Na}^{+}$. On the other hand, this cation-cation repulsion can be removed by the chemical substitution ${ }^{\mathrm{O} 1} \mathrm{~F}^{-} \rightarrow{ }^{\mathrm{O} 1}(\mathrm{OH})^{-}$or the deprotonation process ${ }^{\mathrm{O} 1}(\mathrm{OH})^{-}+$ ${ }_{1 / 4} \mathrm{O}_{2}(\mathrm{~g}) \rightarrow{ }^{\mathrm{O} 1} \mathrm{O}^{2-}+1 / 2 \mathrm{H}_{2} \mathrm{O}(\mathrm{g})$, both of which would favour the occurrence of fluor-liddicoatite and darrellhenryite type arrangements $(Y Y Y)-{ }^{\mathrm{O} 1}(\mathrm{O}, \mathrm{F})-{ }^{X}(\mathrm{Na}, \mathrm{Ca})$.

\section{Optical spectra}

With the exception of the broad absorption band at $\sim 9500 \mathrm{~cm}^{-1}$, the characteristics (band energy, band width and polarisation) of all observed bands in the spectra of the present sample are in very good agreement with those recorded for $\mathrm{Mn}^{3+}$-bearing tourmaline specimens (Reinitz and Rossman, 1988; Ertl et al., 2005; Novák et al., 2013; Bosi et al., 2017a). In agreement with these previously published studies we assign bands at 21,950, 19,800, $\sim 18,000,13,500 \mathrm{~cm}^{-1}$ to electronic transitions in octahedrally coordinated $\mathrm{Mn}^{3+}$ and the very weak and sharp band at 24,330 $\mathrm{cm}^{-1}$ to an electronic transition in octahedrally coordinated $\mathrm{Mn}^{2+}$. The set of strongly E\|c-polarised, sharp bands in the
Fig. 10. Simplified structure of tourmaline showing the relative positions of $\mathrm{H} 1, \mathrm{H} 3, \mathrm{O} 1, \mathrm{O} 3$ and $\mathrm{X}$ with respect to $\mathrm{Y}, \mathrm{Z}$ and the ring of tetrahedra $\mathrm{TO}_{4}$. Of particular interest is the strong interaction between $\mathrm{X}$ and $\mathrm{H} 1$ (distance $\approx 2.21 \AA$ ) and the very weak interaction between $\mathrm{X}$ and $\mathrm{H} 3$ (distance $\approx 3.65 \AA$ ).

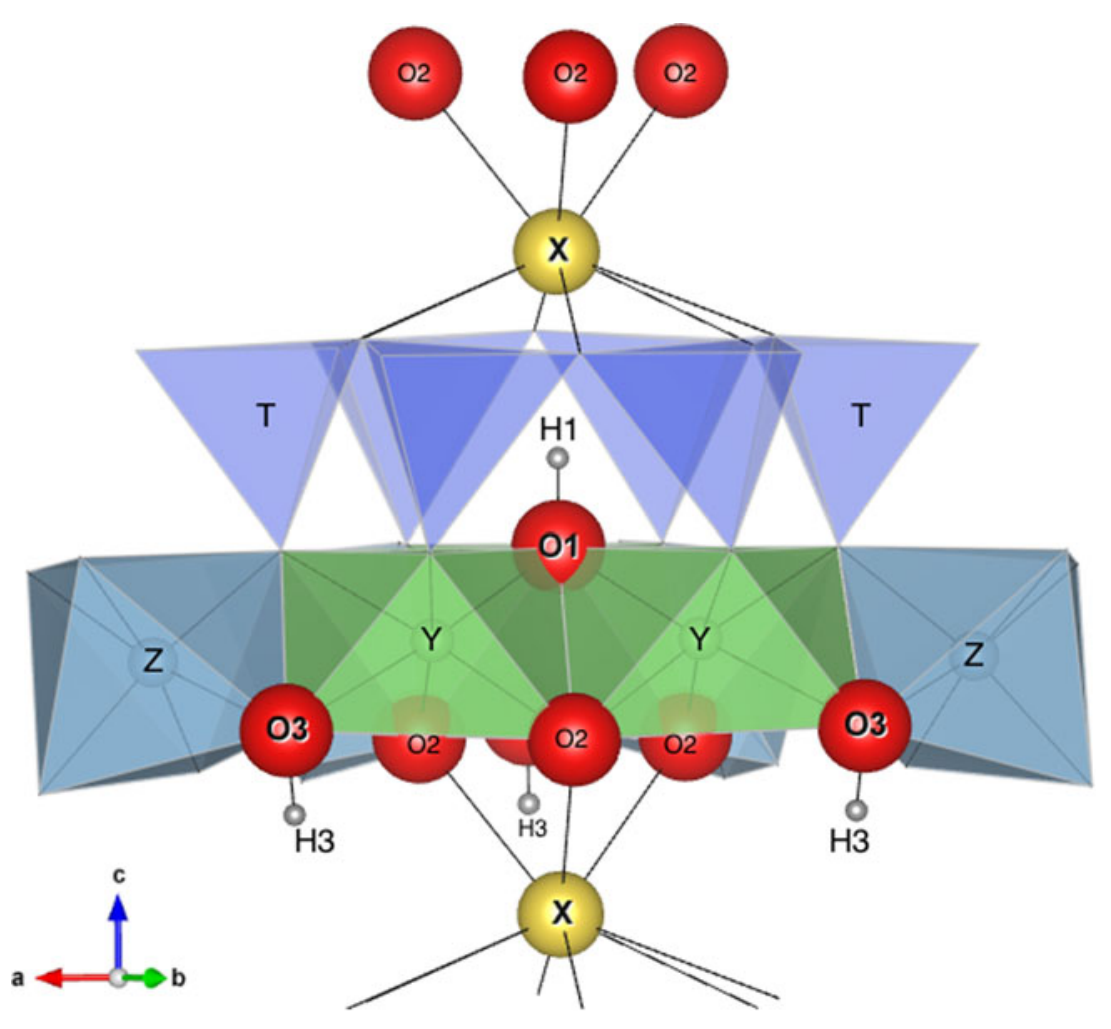


NIR region between $6700-7200 \mathrm{~cm}^{-1}$ are due to overtones of the fundamental $(\mathrm{OH})$-stretching modes.

Based on the intensity of the $\mathrm{Mn}^{3+}$ band at $\sim 18,000 \mathrm{~cm}^{-1}$ in the spectrum perpendicular to the c-axes (Fig. 6) in combination with the published molar absorption coefficient for that absorption band (Reinitz and Rossman, 1988), we calculate an $\mathrm{Mn}_{2} \mathrm{O}_{3}$ content of $\sim 1$ wt.\%. However, the strong intensity increase by a factor of $\sim 4 \times$ for this band in spectra of our heat-treated sample, in combination with the analysed $\mathrm{MnO}_{\text {tot }}$ content, strongly suggests that the absorption coefficient for the band is somewhat higher than that indicated by Reinitz and Rossman (1988). Assuming that all $\mathrm{Mn}^{2+}$ was oxidised to $\mathrm{Mn}^{3+}$ during the heat treatment of our sample we determine an absorption coefficient of $\sim 301 \mathrm{~mole}^{-1} \mathrm{~cm}^{-1}$, compared to the value of $\sim 7.5$ suggested by Reintitz and Rossman (1988). Based on this revised absorption coefficient we calculate a $\mathrm{Mn}_{2} \mathrm{O}_{3}$ content of $\sim 0.2 \mathrm{wt} . \%$ for the untreated sample.

In view of the limited set of transition metals $(\mathrm{Mn}, \mathrm{Fe}$ and $\mathrm{Ti})$ in the present tourmaline, the number of potential origins for the broad absorption band recorded at $\sim 9500 \mathrm{~cm}^{-1}$ is very limited as well. The broadness of this band and its relatively high intensity exclude that it is caused by electron transitions in $\mathrm{Mn}^{2+}$ or $\mathrm{Fe}^{3+}$, which all give rise to much weaker and also sharper spinforbidden absorption bands. Furthermore, redox potential arguments exclude the presence of $\mathrm{Fe}^{2+}$ in a $\mathrm{Mn}^{3+}$-bearing substance. Finally, $\mathrm{Ti}^{4+}$ is not a chromophore and $\mathrm{Ti}^{3+}$ is also excluded on the basis of redox potential considerations. Consequently, there remain only transitions in $\mathrm{Mn}^{3+}$ as a cause for the $\sim 9500 \mathrm{~cm}^{-1}$ band. This assignment is in agreement with observations of a broad $\mathrm{Mn}^{3+}$-related absorption band at $\sim 1040 \mathrm{~nm}$ (corresponding to $\sim 9615 \mathrm{~cm}^{-1}$ ) in optical spectra of oxidised $\mathrm{Mn}^{2+}$-rich elbaite (Ertl et al., 2012). It is also in agreement with the observed increase in band intensity on heat treatment (oxidation) of the present sample. The relatively low energy of this band offers two main alternative assignment schemes. Firstly, low-energy bands caused by transitions in $\mathrm{Mn}^{3+}$ are frequently observed in spectra of substances, in which the cation is at the centre of octahedra that are characterised by one or two metal-ligand bonds deviating strongly from the remaining ones, either by being considerably shorter or longer (Burns, 1993). Secondly, transitions in tetrahedrally coordinated ${ }^{[4]} \mathrm{Mn}^{3+}$ may also give rise to spectral bands of relatively low energy, as shown by a broad absorption band at $10,800 \mathrm{~cm}^{-1}$ in spectra of ${ }^{[4]} \mathrm{Mn}^{3+}$-doped spinel (Bosi et al., 2007). The observed intensity increase for the $\sim 9500 \mathrm{~cm}^{-1}$ band in response to heat treatment, i.e. oxidation, represents a strong argument against this second suggestion, as this would require $\mathrm{Mn}^{2+}$ to be located initially at the tetrahedrally coordinated sites of tourmaline, which is highly unlikely (Bačík and Fridrichová, 2020). Furthermore, the SREF results provides no indications for ${ }^{[4]} \mathrm{Mn}^{3+}$ and consequently we prefer the suggestion that the band is caused by a transition in $\mathrm{Mn}^{3+}$ cations at octahedrally coordinated sites, where the local electronic field around the cation is strongly distorted from the $O_{h}$ symmetry.

\section{Conclusions}

The comprehensive multi-analytical approach of the present study shows that the gem-quality purplish-red colour of the hand specimen of elbaite from the Anjanabonoina pegmatite (Madagascar) is caused by $\mathrm{Mn}^{3+}$, which occurs as a minor element $\left(\mathrm{Mn}_{2} \mathrm{O}_{3}=0.20 \mathrm{wt} . \%\right.$, corresponding to $\left.0.02 \mathrm{apfu}\right)$. The colour intensity strongly increases with increasing $\mathrm{Mn}^{3+}$ concentrations $\left(\mathrm{Mn}_{2} \mathrm{O}_{3}\right.$ up to $1.21 \mathrm{wt} \%$, corresponding to $\left.0.15 \mathrm{apfu}\right)$.

Although the bulk chemical composition of the present sample corresponds to elbaite, based on the electrostatic $\mathrm{H}^{+}-\mathrm{Na}^{+}$repulsion, the more intense FTIR bands related to $\mathrm{O} 1$ could be ascribed to the rossmanite-type arrangements $(Y Y Y)-{ }^{\mathrm{O} 1}(\mathrm{OH}){ }^{X}(\square)$ rather than elbaite-type ones $(Y Y Y)-{ }^{\mathrm{O} 1}(\mathrm{OH})-{ }^{X}(\mathrm{Na})$.

Following this model of the electrostatic interaction between the $\mathrm{X}$ cation and $\mathrm{W}$ anions, the substitution $\mathrm{F}^{-} \rightarrow(\mathrm{OH})^{-}$as well as the removal of $\mathrm{H}$ from the ${ }^{\mathrm{w}}(\mathrm{OH})$ group would favour the occurrence of fluor-liddicoatite- and darrellhenryite-type clusters. On the other hand, the presence of $\mathrm{H}$ in the ${ }^{\mathrm{w}}(\mathrm{OH})$ group could explain the absence or rarity of tourmalines such as "liddicoatite', ideally $\mathrm{Ca}\left(\mathrm{Li}_{2} \mathrm{Al}\right) \mathrm{Al}_{6} \mathrm{Si}_{6} \mathrm{O}_{18}\left(\mathrm{BO}_{3}\right)_{3}(\mathrm{OH})_{3} \mathrm{OH}$. The latter is still, in fact, a missing mineral species. Similar arguments might be applied to uvite, $\mathrm{CaMg}_{3} \mathrm{Al}_{6} \mathrm{Si}_{6} \mathrm{O}_{18}\left(\mathrm{BO}_{3}\right)_{3}(\mathrm{OH})_{3} \mathrm{OH}$ (Bosi et al., 2020), but in this case we have to consider the increased total charge at the $Y$ site of uvite $(+6)$ compared to 'liddicoatite' $(+5)$, which may accommodate composition with a strong $\mathrm{H}^{+}-$ $\mathrm{Ca}^{2+}$ repulsive effect. In this regard, Ertl and Bačík (2020) described the correlations between the $\mathrm{F}$ content and the $X$-site charge, whereas Henry and Dutrow (2011) showed: (1) that interaction among the $X, Y$ and $\mathrm{O} 1$ sites can accommodate unfavourable compositions; (2) the latter may also be influenced by the petrological environment, which may yield deviation from the limitations imposed by the tourmaline crystal chemistry. Bosi et al. (2017b) showed that direct correlation between $\mathrm{F}$ and $\mathrm{Cr}$ observed in Cr tourmalines from the Sludyanka complex, Lake Baikal, Russia, requires the occurrence of the local arrangements ${ }^{\mathrm{Y}}(\mathrm{CrCrCr}){ }^{\mathrm{O} 1}(\mathrm{~F})$, which should be unstable from a short-range bond-valence perspective (e.g. Bosi, 2013, 2018).

Supplementary material. To view supplementary material for this article, please visit https://doi.org/10.1180/mgm.2021.20

Acknowledgements. Chemical analyses were completed with the kind assistance of M. Serracino, to whom the authors express their gratitude. Funding by Sapienza University of Rome (Prog. Università 2018 to F. Bosi) is gratefully acknowledged. We thank F. Pezzotta for providing the photo of the sample analysed in this study. Comments and suggestions by the Associate Editor Ian T. Graham, A. Ertl and two anonymous reviewers were much appreciated.

\section{References}

Ahmadi S., Tahmasbi Z., Khalaji A.A. and Zal F. (2019) Chemical variations and origin of tourmalines in laleh zar granite of Kerman (Southeast Iran). Periodico di Mineralogia, 88, 117-129.

Andreozzi G.B., Bosi F., Celata B., Capizzi L.S., Stagno V. and Beckett-Brown C. (2020) Crystal-chemical behavior of $\mathrm{Fe}^{2+}$ in tourmaline dictated by structural stability: insights from a schorl with formula $\mathrm{Na}^{\mathrm{Y}}\left(\mathrm{Fe}_{2}^{2+} \mathrm{Al}\right)^{\mathrm{Z}}\left(\mathrm{Al}_{5} \mathrm{Fe}^{2+}\right)$ $\left(\mathrm{Si}_{6} \mathrm{O}_{18}\right)\left(\mathrm{BO}_{3}\right)_{3}(\mathrm{OH})_{3}(\mathrm{OH}, \mathrm{F})$ from Seagull batholith (Yukon Territory, Canada). Physics and Chemistry of Minerals, 47, 25.

Aurisicchio C., Demartin F., Ottolini L. and Pezzotta F. (1999) Homogeneous liddicoatite from Madagascar: a possible reference material? First EMPA, SIMS and SREF data. European Journal of Mineralogy, 11, 237-242.

Bačík P. and Fridrichová G. (2020) Cation partitioning among crystallographic sites based on bond-length constraints in tourmaline-supergroup minerals. American Mineralogist, https://doi.org/10.2138/am-2021-7804

Berryman E.J., Wunder B., Ertl A., Koch-Müller M., Rhede D., Scheidl K., Giester G. and Heinrich W. (2016) Influence of the X-site composition on tourmaline's crystal structure: Investigation of synthetic K-dravite, dravite, oxy-uvite, and magnesio-foitite using SREF and Raman spectroscopy. Physics and Chemistry of Minerals, 43, 83-102. 
Bosi F. (2013) Bond-valence constraints around the O1 site of tourmaline. Mineralogical Magazine, 77, 343-351.

Bosi F. (2014) Bond valence at mixed occupancy sites. I. Regular polyhedra. Acta Crystallographica, B70, 864-870.

Bosi F. (2018) Tourmaline crystal chemistry. American Mineralogist, 103, 298-306.

Bosi F. and Andreozzi G.B. (2013) A critical comment on Ertl et al. (2012): "Limitations of $\mathrm{Fe}^{2+}$ and $\mathrm{Mn}^{2+}$ site occupancy in tourmaline: Evidence from $\mathrm{Fe}^{2+}$ - and $\mathrm{Mn}^{2+}$-rich tourmaline". American Mineralogist, 98, 21832192.

Bosi F. and Lucchesi S. (2007) Crystal chemical relationships in the tourmaline group: structural constraints on chemical variability. American Mineralogist, 92, 1054-1063.

Bosi F. and Skogby H. (2013) Oxy-dravite, $\mathrm{Na}\left(\mathrm{Al}_{2} \mathrm{Mg}\right)\left(\mathrm{Al}_{5} \mathrm{Mg}\right)\left(\mathrm{Si}_{6} \mathrm{O}_{18}\right)$ $\left(\mathrm{BO}_{3}\right)_{3}(\mathrm{OH})_{3} \mathrm{O}$, a new mineral species of the tourmaline supergroup. American Mineralogist, 98, 1442-1448.

Bosi F., Agrosi G., Lucchesi S., Melchiorre G. and Scandale E. (2005) Mn-tourmaline from island of Elba (Italy). Crystal chemistry. American Mineralogist, 90, 1661-1668.

Bosi F., Hålenius U., Andreozzi G.B., Skogby H. and Lucchesi S. (2007) Structural refinement and crystal chemistry of Mn-doped spinel: a case for tetrahedrally coordinated $\mathrm{Mn}^{3+}$ in an oxygen-based structure. American Mineralogist, 92, 27-33.

Bosi F., Skogby H., Agrosì G. and Scandale E. (2012) Tsilaisite, $\mathrm{NaMn}_{3} \mathrm{Al}_{6}\left(\mathrm{Si}_{6} \mathrm{O}_{18}\right)\left(\mathrm{BO}_{3}\right)_{3}(\mathrm{OH})_{3} \mathrm{OH}$, a new mineral species of the tourmaline supergroup from Grotta d'Oggi, San Pietro in Campo, island of Elba, Italy. American Mineralogist, 97, 989-994.

Bosi F., Andreozzi G.B., Skogby H., Lussier A.J., Abdu Y. and Hawthorne F.C. (2013) Fluor-elbaite, $\mathrm{Na}\left(\mathrm{Li}_{1.5} \mathrm{Al}_{1.5}\right) \mathrm{Al}_{6}\left(\mathrm{Si}_{6} \mathrm{O}_{18}\right)\left(\mathrm{BO}_{3}\right)_{3}(\mathrm{OH})_{3} \mathrm{~F}$, a new mineral species of the tourmaline supergroup. American Mineralogist, 98, 297-303.

Bosi F., Skogby H., Lazor P. and Reznitskii L. (2015) Atomic arrange- ments around the $\mathrm{O} 3$ site in $\mathrm{Al}$ - and $\mathrm{Cr}$-rich oxy-tourmalines: a combined EMP, SREF, FTIR and Raman study. Physics and Chemistry of Minerals, 42, 441-453.

Bosi F., Skogby H. and Hålenius U. (2016a) Thermally induced cation redistribution in Fe-bearing oxy-dravite and potential geothermometric implications. Contributions to Mineralogy and Petrology, 171, 47.

Bosi F., Skogby H. and Balić-Žunić T. (2016b) Thermal stability of extended clusters in dravite: a combined EMP, SREF and FTIR study. Physics and Chemistry of Minerals, 43, 395-407.

Bosi F., Cámara F., Ciriotti M.E., Hålenius U., Reznitskii L. and Stagno V. (2017a) Crystal-chemical relations and classification problems of tourmalines belonging to the oxy-schorl-oxy-dravite-bosiite-povondraite series. European Journal of Mineralogy, 29, 445-455.

Bosi F., Reznitskii L., Hålenius U. and Skogby H. (2017b) Crystal chemistry of Al-V-Cr oxy-tourmalines from Sludyanka complex, Lake Baikal, Russia. European Journal of Mineralogy, 29, 457-472.

Bosi F., Naitza S., Skogby H., Secchi F., Conte A.M., Cuccuru S., Hålenius U., De La Rosa N., Kristiansson P., Charlotta Nilsson E.J., Ros L. and Andreozzi G.B. (2018) Late magmatic controls on the origin of schorlitic and foititic tourmalines from late-Variscan peraluminous granites of the Arbus pluton (SW Sardinia, Italy): Crystal-chemical study and petrological constraints. Lithos, 308-309, 395-411.

Bosi F., Biagioni C. and Oberti R. (2019a) On the chemical identification and classification of minerals. Minerals, 9, 591.

Bosi F., Hatert F., Hålenius U., Pasero M., Miyawaki R. and Mills S.J. (2019b) On the application of the IMA-CNMNC dominant-valency rule to complex mineral compositions. Mineralogical Magazine, 83, 627-632.

Bosi F., Naitza S., Secchi F., Conte A.M., Cuccuru S., Andreozzi G.B., Skogby H. and Hålenius U. (2019c) Petrogenetic controls on the origin of tourmalinite veins from Mandrolisai igneous massif (Central Sardinia, Italy): Insights from tourmaline crystal chemistry. Lithos, 342-343, 333-344.

Bosi F., Skogby H. and Hålenius U. (2019d) Thermally induced cation redistribution in fluor-elbaite and Fe-bearing tourmalines. Physics and Chemistry of Minerals, 46, 371-383.

Bosi F., Biagioni C., Pezzotta F., Skobgy H., Hålenius U., Cempírek J., Hawthorne F.C., Lussier A.J., Abdu Y.A., Day M.C., Fayek M., Clark C.M., Grice J.D. and Henry D.J. (2020) Uvite, IMA 2019-113. CNMNC
Newsletter No. 54, April 2020, page 362. Mineralogical Magazine, 84, 359-365

Brown I.D. and Altermatt D. (1985) Bond-valence parameters obtained from a systematic analysis of the Inorganic Crystal Structure Database. Acta Crystallographica, B41, 244-247.

Burns R.G. (1993) Mineralogical Applications of Crystal Field Theory. 2nd ed., 576 p. Cambridge University Press, Cambridge, U.K.

Cempírek J., Houzar S., Novák M., Groat L.A., Selway J.B. and Šrein V. (2013) Crystal structure and compositional evolution of vanadium-rich oxy-dravite from graphite quartzite at Bítovánky, Czech Republic. Journal of Geosciences, 58, 149-162.

De Vito C., Aurisicchio C., Ferrini V. and Pezzotta F. (2002a) Nb-Ta oxides from Anjanabonoina pegmatite. International Mineralogical Association $18^{\text {th }}$ General Meeting (Edinburgh), Program Abstract, 275.

De Vito C., Aurisicchio C., Ferrini V. and Pezzotta F. (2002b) Chemical composition and $\mathrm{B}, \mathrm{O}$ and $\mathrm{H}$ isotopes of tourmaline from Anjanabonoina pegmatite. International Mineralogical Association, $18^{\text {th }}$ General Meeting (Edinburgh), Program Abstract, 208.

Dirlam D.M., Laurs B.M., Pezzotta F. and Simmons W.B. (2002) Liddicoatite tourmaline from Anjanabonoina, Madagascar. Gems \& Gemology, 38, 28-53.

Dunn P.J., Appleman D.E. and Nelen J.E. (1977) Liddicoatite, a new calcium end member of the tourmaline group. American Mineralogist, 62, 1121-1124.

Dutrow B.L. and Henry D.J. (2018) Tourmaline compositions and textures: reflections of the fluid phase. Journal of Geosciences, 63, 99-110.

Ertl A. and Bacík P. (2020) Considerations about Bi and Pb in the crystal structure of Cu-bearing tourmaline. Minerals, 10, 706.

Ertl A., Hughes J.M., Pertlik F., Foit F.F. Jr., Wright S.E., Brandstatter F. and Marler B. (2002) Polyhedron distortions in tourmaline. The Canadian Mineralogist, 40, 153-162.

Ertl A., Rossman G.R., Hughes J.M., Prowatke S. and Ludwig T. (2005) Mn-bearing "oxy-rossmanite" with tetrahedrally coordinated Al and B from Austria: Structure, chemistry and infrared and optical spectroscopic study. American Mineralogist, 90, 481-487.

Ertl A., Hughes J.M., Prowatke S., Ludwig T., Prasad P.S.R., Brandstätter F., Körner W., Schuster R., Pertlik F. and Marschall H. (2006) Tetrahedrally coordinated boron in tourmalines from the liddicoatite-elbaite series from Madagascar: Structure, chemistry, and infrared spectroscopic studies. American Mineralogist, 91, 1847-1856.

Ertl A., Kolitsch U., Dyar D., Hughes J.M., Rossman G.R., Pieczka A., Henry D.J., Pezzotta F., Prowatke S., Lengauer C.L., Körner W., Brandstätter F., Francis C. A., Prem M. and Tillmanns E. (2012) Limitations of $\mathrm{Fe}^{2+}$ and $\mathrm{Mn}^{2+}$ site occupancy in tourmaline: Evidence from $\mathrm{Fe}^{2+}$ and $\mathrm{Mn}^{2+}$-rich tourmaline. American Mineralogist, 97, 1402-1416.

Ertl A., Henry D.J. and Tillmanns E. (2018) Tetrahedral substitutions in tourmaline: a review. European Journal of Mineralogy, 30, 465-470.

Fabre C., Boiron M.C., Dubessy J., Chabiron A., Charoy B. and Crespo T.M. (2002) Advances in lithium analysis in solids by means of laser-induced breakdown spectroscopy: An exploratory study. Geochimica et Cosmochimica Acta, 66, 1401-1407.

Fernandez A., Huber S., Schreurs G., Villa I. and Rakotondrazafy M. (2001) Tectonic evolution of the Itremo region (central Madagascar) and implications for Gondwana assembly. Gondwana Research, 4, 165-168.

Filip J., Bosi F., Novák M., Skogby H., Tuček J., Čuda J. and Wildner M. (2012) Redox processes of iron in the tourmaline structure: example of the hightemperature treatment of $\mathrm{Fe}^{3+}$-rich schorl. Geochimica et Cosmochimica Acta, 86, 239-256.

Foit F.F. Jr. (1989) Crystal chemistry of alkali-deficient schorl and tourmaline structural relationships. American Mineralogist, 74, 422-431.

Gatta G.D., Bosi F., McIntyre G.J. and Skogby H. (2014) First accurate location of two proton sites in tourmaline: A single-crystal neutron diffraction study of oxy-dravite. Mineralogical Magazine, 78, 681-692.

Gonzalez-Carreño T., Fernandez M. and Sanz J. (1988) Infrared and electron microprobe analysis in tourmalines. Physics and Chemistry of Minerals, 15, $452-460$.

Grew E.S., Krivovichev S.V., Hazen R.M. and Hystad G. (2016) Evolution of structural complexity in boron minerals. The Canadian Mineralogist, 54, $125-143$. 
Grew E.S., Bosi F., Gunter M., Hålenius U., Trumbull R.B. and Yates M.G. (2018) Fluor-elbaite, lepidolite and $\mathrm{Ta}-\mathrm{Nb}$ oxides from a pegmatite of the 3000 MA Sinceni pluton, Swaziland: Evidence for lithium-cesium-tantalum (LCT) pegmatites in the Mesoarchean. European Journal of Mineralogy, 30, 205-218.

Grice J.D. and Ercit T.S. (1993) Ordering of Fe and Mg in the tourmaline crystal structure: the correct formula. Neues Jahrbuch für Mineralogie, Abhandlungen, 165, 245-266.

Henry D.J. and Dutrow B.L. (1996) Metamorphic tourmaline and its petrologic applications. Pp. 503-557 in: Boron: Mineralogy, Petrology and Geochemistry (E.S. Grew and L.M. Anvitz, editors). Reviews in Mineralogy and Geochemistry, vol. 33. Mineralogical Society of America, Chantilly, Virginia, USA.

Henry D.J. and Dutrow B.L. (2011) The incorporation of fluorine in tourmaline: Internal crystallographic controls or external environmental influences? The Canadian Mineralogist, 49, 41-56.

Henry D.J. and Dutrow B.L. (2018) Tourmaline studies through time: contributions to scientific advancements. Journal of Geosciences, 63, 77-98.

Henry D.J., Novák M., Hawthorne F.C., Ertl A., Dutrow B., Uher P. and Pezzotta F. (2011) Nomenclature of the tourmaline-supergroup minerals. American Mineralogist, 96, 895-913.

Horiba Jobin Yvon GmbH $(2004,2005)$ LabSpec software for Raman spectroscopic data analysis, acquisition and manipulation. Version 5.64.15. HORIBA Jobin Yvon SAS, Villeneuve d'Ascq, France.

Hughes J.M., Ertl A., Dyar M.D., Grew E.S., Wiedenbeck M. and Brandstätter F. (2004) Structural and chemical response to varying ${ }^{[4]} \mathrm{B}$ content in zoned Fe-bearing olenite from Koralpe, Austria. American Mineralogist, 89, 447-454.

Kutzschbach M., Wunder B., Rhede D., Koch-Müller M., Ertl A., Giester G., Heinrich W. and Franz G. (2016) Tetrahedral boron in natural and synthetic HP/UHP tourmaline: evidence from Raman spectroscopy, EMPA, and single-crystal XRD. American Mineralogist, 101, 93-104.

Libowitzky E. (1999) Correlation of O-H stretching frequencies and O-H $\cdots \mathrm{O}$ hydrogen bond lengths in minerals. Monatshefte für Chemie, 130, 10471059.

Lussier A.J. and Hawthorne F. (2011) Oscillatory zoned liddicoatite from Anjanabonoina, central Madagascar. II. Compositional variation and mechanism of substitution. The Canadian Mineralogist, 49, 89-103.

Lussier A.J., Abdu Y., Hawthorne F.C., Michaelis V.K., Aguiar P.M. and Kroeker S. (2011) Oscillatory zoned liddicoatite from Anjanabonoina, central Madigascar. I. Crystal chemistry and structure by SREF and ${ }^{11} \mathrm{~B}$ and ${ }^{27} \mathrm{Al}$ MAS NMR spectroscopy. The Canadian Mineralogist, 49, 63-88.

McKeown D.A. (2008) Raman spectroscopy, vibrational analysis, and heating of buergerite tourmaline. Physics and Chemistry of Minerals, 35, 259-270.

McMillan N.J., McManus C.E., Harmon R.S., De Lucia Jr., F.C. and Miziolek A.W. (2006) Laser induced breakdown spectroscopy analysis of complex silicate minerals - beryl. Analytical and Bioanalytical Chemistry, 385, 263-27.

McMillan N.J., Curry J., Dutrow B.L. and Henry D.J. (2018) Identification of the host lithology of tourmaline using laser-induced breakdown spectroscopy for application in sediment provenance and mineral exploration. The Canadian Mineralogist, 56, 393-410.

Mihailova B., Gasharova B. and Konstantinov L. (1996) Influence on nontetrahedral cations in $\mathrm{Si}-\mathrm{O}$ vibrations in complex silicates. Journal of Raman Spectroscopy, 27, 829-833.

Novák M., Povondra P. and Selway J.B. (2004) Schorl-oxy-schorl to dravite-oxydravite tourmaline from granitic pegmatites; examples from the Moldanubicum, Czech Republic. European Journal of Mineralogy, 16, 323-333.

Novák M., Škoda P., Filip J., Macek I. and Vaculovič T. (2011) Compositional trends in tourmaline from intragranitic NYF pegmatites of the Třebíc Pluton, Czech Republic; electron microprobe, Mössbauer and LA-ICP-MS study. The Canadian Mineralogist, 49, 359-380.

Novák M., Ertl A., Povondra P., Vašinová Galiová M., Rossman G.R., Pristacz H., Prem M., Giester G., Gadas P. and Škoda R. (2013) Darrellhenryite, Na
$\left(\mathrm{LiAl}_{2}\right) \mathrm{Al}_{6}\left(\mathrm{BO}_{3}\right)_{3} \mathrm{Si}_{6} \mathrm{O}_{18}(\mathrm{OH})_{3} \mathrm{O}$, a new mineral from the tourmaline supergroup. American Mineralogist, 98, 1886-1892.

Paquette J.L. and Nédélec A. (1998) A new insight into Pan-African tectonics in the East-West Gondwana collision zone by $\mathrm{U}-\mathrm{Pb}$ zircon dating of granites from central Madagascar. Earth and Planetary Science Letters, 155, 45-56.

Pezzotta F. (1999) Madagaskar - Das Paradies der Mineralien und Edelsteine. Extra Lapis, 17, 56-59 [in German].

Pezzotta F. and Franchi M. (1997) Miarolitic shallow depth pegmatites of the Betafo and Antsirabe areas, central Madagascar; genetic inferences. P. 71 in: Proceedings of the UNESCO-IUGS-IGCP-348/368 International Field Workshop on Proterozoic Geology of Madagascar, Antananarivo, August 16-30 (R. Cox and L.D. Ashwal, editors). Gondwana Research Group Miscellaneous Publication No. 5.

Pezzotta F. and Laurs B.M. (2011) Tourmaline: The kaleidoscopic gemstone. Elements, 7, 331-336.

Pouchou J.L. and Pichoir F. (1991) Quantitative analysis of homogeneous or stratified microvolumes applying the model "PAP". Pp. 31-75 in: Electron Probe Quantitation (K.F.J. Heinrich and D.E. Newbury, editors). Plenum, New York.

Reddy B.J., Frost R.L., Martens W.N., Wain D.L. and Kloprogge J.T. (2007) Spectroscopic characterization of Mn-rich tourmalines. Vibrational Spectroscopy, 44, 42-49.

Reinitz I. and Rossman G.R. (1988) Role of natural radiation in tourmaline coloration. American Mineralogist, 73, 822-825.

Sheldrick G.M. (2015) Crystal structure refinement with SHELXL. Acta Crystallographica, C71, 3-8.

Skogby H., Bosi F. and Lazor P. (2012) Short-range order in tourmaline: a vibrational spectroscopic approach to elbaite. Physics and Chemistry of Minerals, 39, 811-816.

Strunz H. (1979) Anjanabonoina, Fundort schönster Tourmaline. Lapis, 1, $24-$ 27, 47-48 [in German].

Sweetapple M.T. and Tassios S. (2015) Laser-induced breakdown spectroscopy (LIBS) as a tool for in situ mapping and textural interpretation of lithium in pegmatite minerals. American Mineralogist, 100, 2141-2151.

Tempesta G. and Agrosì G. (2016) Standardless, minimally destructive chemical analysis of red beryls by means of laser induced breakdown spectroscopy. European Journal of Mineralogy, 28, 571-580.

Tempesta G., Bosi F. and Agrosì G. (2020) Crystal chemical characterisation of red beryl by 'standardless' laser-induced breakdown spectroscopy and single-crystal refinement by X-ray diffraction: an example of validation of an innovative method for the chemical analysis of minerals. Geostandards and Geoanalytical Research, 44, 685-693.

van Hinsberg V.J., Henry D.J. and Dutrow B.L. (2011a) Tourmaline as a petrologic forensic mineral: a unique recorder of its geologic past. Elements, 7, 327-332.

van Hinsberg V.J., Henry D.J. and Marschall H.R. (2011b) Tourmaline: an ideal indicator of its host environment. The Canadian Mineralogist, 49, $1-16$.

Webber K.L., Simmons W.B. and Falster A.U. (2002) Tourmaline from the Antandrokomby and Fianarantsoa Pegmatites, Madagascar. Mineralogical Record, 33, 82.

Watenphul A., Burgdorf M., Schlüter J., Horn I., Malcherek T. and Mihailova B. (2016a) Exploring the potential of Raman spectroscopy for crystallochemical analyses of complex hydrous silicates: II. Tourmalines. American Mineralogist, 101, 970-985.

Watenphul A., Schlüter J., Bosi F., Skogby H., Malcherek T. and Mihailova B. (2016b) Influence of the octahedral cationic-site occupancies on the framework vibrations of Li-free tourmalines, with implications for estimating temperature and oxygen fugacity in host rocks, American Mineralogist, 101, 2554-2563.

Wojdyr M. (2010) Fityk: a general-purpose peak fitting program. Journal of Applied Crystallography, 43, 1126-1128. 